\title{
Problem-Solving Behavior and Theories of Tort Liability
}

\author{
Howard A. Latin†
}

The most influential mode of torts analysis in recent decades has treated liability as a mechamism for social engineering in the sense that accident losses should be allocated to particular parties in order to induce efficient cost-minimizmg behavior by similarly situated actors. Behavior modification is, for example, an explicit requirement of the familiar Calibresian tort goals: reduction of primary accident losses where accident costs exceed prevention costs, reduction of secondary losses or "dislocation" costs through loss-spreading arrangements, reduction of administrative costs including litigation and insurance expenses, and minimization of curnulative accident costs within the constraint of "fairness."1 Although cominentators disagree on which liability theories will best accomplisl these tort goals, virtually all social engineering and "law and econoinics" analyses ${ }^{2}$ share one central behavioral assumption-that inposition of liability substantially affects low categories of actors respond to the risks they create or confront. ${ }^{3}$

$\dagger$ Professor of Law, Rutgers University School of Law at Newark. B.A. 1966, Brandeis University; J.D. 1974, Boalt Hall School of Law, University of California, Berkeley.

I wish to thank Dean Guido Calabresi and Professors Allan Axelrod, Robert Ellickson, John Kaplan, Janies Paul, Alan Schwartz, and Marshall Sliapo for their useful comments on drafts of this essay. I also thank Reuee Dossick and Richard Brown, Rutgers Law School Class of 1986, for their research assistance.

1. See G. Calabresi, The Costs of Accidents 24-94 (1970). I accept Calabresi's conceptual statenient of tort goals for purposes of this Article. There are other possible tort objectives, such as retribution or wealth redistribution, but I have not seen a satisfactory discussion of how these goals may be integrated into an efficiency-based liability theory, and I regard them as outside the scope of this Article. I also do not attenpt in this essay to compare the relative dimensions and adequacy of compensation under existing tort liability, under nly recommended reforms of the tort system, or under alternative compensatiou systemis.

2. The label "social engineering" is used here to denote any liability system prinarily intended to pronote efficient beliavior modification. The "law and economics" tort literature represents one genre of social engineering analysis, but it seldom enıphasizes the actual beliavior of typical actors in diverse accident contexts. Most "law and econonics" treatnents instead incorporate unvalidated behavioral assunıtions, such as rational utility nıaximization or a continuous Bayesian refinement of subjective probability estimates, that are amenable to niathematieal formulations but may not correspond to real beliavior in nany settings.

3. See, eg., R. Posner, EConomic ANAlysis of Law 139, 143 n.2 (2d ed. 1977); Grady, $A$ New Positive Economic Theory of Negligence, 92 YALE L.J. 799, 801-09, 814-21 (1983); Shavell, Strict Liability Versus Negligence, 9 J. LEGAL STUd. 1, 2-3, 7-8 (1980). Any "law and economics" treatment that characterizes people as rational niaximizers necessarily assumes that liability will affect the behavior of all categories of actors in a given accident context. Most other social engineer- 
The assumption that liability generally influences decisions on accident prevention and loss spreading is often based on a characterization of people as "rational utility maximizers" who weigh all personally relevant costs and benefits of alternative courses of action. Liability increases the costs of the designated party's activities and therefore provides an incentive for rational maximizers to include anticipated accident losses in their cost-benefit calculations. This proposition may be expanded into a series of behavioral hypotheses that must all be correct before imposition of tort liability will achieve the predicted results: typical actors must know the liability rules associated with various forms of conduct; they must possess sufficient information and evaluative skills to assess potential risks; they must pay attention to risks and corresponding liability rules when they engage in risky activities; and the category of actors assigned liability must evaluate the costs and benefits of alternative choices in a meaningful manner. ${ }^{4}$ In short, liability rules will promote social engineering objectives only to the extent that prospective injurers and victims can, and typically do, undertake informed problem-solving behavior with respect to the risks for which they may be liable.

In contradiction to the assumption of rational maximizing behavior, many psychologists, decision theorists, and economists maintain that people cannot conceivably examine all possible ramifications of all possible choices. Incomplete information is the most frequently cited extrinsic constraint, ${ }^{5}$ but inherent limitations on human comprehensional capacity, tine, and attention span also impose fundamental constraints on decisionmaking capabilities. ${ }^{6}$ In the words of Herbert Simon, the

ing treatments assume that liability will influence the decisions of at least one category of actors in each accident setting. See, e.g., Calabresi, Optimal Deterrence and Accidents, 84 YALE L.J. 656, 66670 (1975).

4. Throughout this essay, I use the labels "problem-solving risk contexts" and "high-attention risks" as a shorthand way to denote accident contexts in which a category of actors generally meets these four behavioral requirements. If any requirement is absent, I denote the risk as "lowattention."

5. See, e.g., H. RAIFFA, Decision ANAlysis: INTRODUCTORY LECTURES ON ChOICES UNDER UNCERTAINTY (1968); Arrow, Limited Knowledge and Economic Analysis, 64 AM. ECON. REV. 1 (1974); Marschak, Economics of Inquiring, Communicating, Deciding, 1968 AM. ECON. REV. PAPERs \& Proc. 1. For recent discussions of the legal implications of incoinplete information, see, e.g., Beales, Craswell \& Salop, The Efficient Regulation of Constumer Information, 24 J.L. \& EcoN. 491 (1981); Grady, supra note 3; Schwartz \& Wilde, Imperfect Information in Markets for Contract Terms: The Examples of Warranties and Security Interests, 69 VA. L. REV. 1387 (1983). Incomplete information is an "extrinsic constraint" in the sense that it could be reinedied by the provision of additional information from some outside source. In contrast, limitations on human comprehensional capacity, time, and attention span are inherent and are less anenable to external solutions. See Simon, Theories of Bounded Rationality, in 12 STUdies IN MATHEMATICAL AND MANAGERIAL Economics: DECISION AND ORGaNIZATION 161, 162 (C. McGuire \& R. Radner eds. 1972).

6. See, e.g., H. SIMON, MODELS OF MAN 198 (1957); O. WILLIAMSON, MARKETS AND HIERARCHIES: ANALYSIS AND ANTITRUST IMPLICATIONS 9, 134 (1975); Boulding, The Ethics of Rational Decision, in Management: A Decision-Making ApproaCH 93, 100-01 (S. Young ed. 1968); Radner, A Behavior Model of Cost Reduction, 6 BELL J. ECON. 196, 197 (1975); Simon, 
Nobel laureate economist: "The scarce resource is computational capacity-the mind."7 Thinking things through requires time, effort, and diverse evaluative skills, which means people cannot employ effective problem-solving behavior for more than a small subset of the choices they must make. ${ }^{8}$ If the primary purpose of tort liability is to encourage efficient behavior modification, then liability rules should be tailored to the actual risk-avoidance behavior of categories of actors in diverse accident settings. The proposition that problem-solving ability and attention span are severely restricted by cognitive constraints provides the foundation for this article's normative analysis of competing tort liability theories and alternative compensation systems.

In Part I of the Article, I describe the implications for tort law of limited problem-solving ability and develop several themes essential to my analysis. People routinely are faced with a broad constellation of risks and cannot conduct meamingful cost-benefit assessments for most of them. Even well-informed people often do not modify their actions in light of "known" risks and liabihity rules because at the critical moment their limited attention and cognitive capacity are focused elsewhere. ${ }^{9}$ Some people do, however, respond to specific risks in an informed and attentive manner, especially when they are acting in an organizational or commercial setting. Imposition of tort liability on potential injurers or victims will significantly affect their behavior, and thereby encourage cost minimization, only when that category of actors is likely to engage in problem-solving with respect to a particular type of risk. In other accident contexts, hability rules will have little effect from a social engineerimg perspective. ${ }^{10}$ Because informed problem-solving behavior is a prerequisite for efficient cost-mimmization decisions, liability should often be assigned to problem-solving actors to create an incentive for

Rationality as Process and as Product of Thought, 1978 AM. Econ. Rev. PAPERs \& Proc. 1, 12-13. Professor Simon coined the phrase "bounded rationality" to describe decisionmaking constraints arising from inherent limitations on comprehensional capacity, time, and attention. I use the more general term "problem-solving constraints" to imdicate that human decisionmaking is limited by both extrinsic and intrinsic factors.

7. Simon, supra note 6 , at 12.

8. See id. at 12-14; G. Katona, Psychological Economics 218-19, $225-26$ (1975); R. MARKin, Consumer Behavior: A COGNITIVE ORIENTATION 542 (1974).

9. I believe many important kinds of accidents, such as those associated with driving and product uses, more often stem from periodic inattention than from lack of adequate knowledge. See infra notes 57-61, 233-35 and accompanying text.

10. The imposition of liability on problem-solving actors is likely to influence their decisions whether to take precautionary measures or to insure against losses when they believe prevention is not feasible. Assignment of losses to categories of actors that are not proficient problem solvers raises the price of risky activities and therefore may decrease the levels of those activities, but it will seldom induce those actors to change their risk-avoidance decisionmaking. For a more detailed discussion of this point, see infra notes 107-13, 239-55 and accompanying text. 
them to protect uninformed or inattentive people against their own lack of care.

In Part II, I contend that a single theory of tort liability cannot prove optimum for all accident contexts because the same people treat disparate risks differently, various people treat the same risks differently, and different people undertake problem-solving behavior for diverse types of activities. In conjunction with this proposition, Part II introduces a matrix that links "high-attention" and "low-attention" risk categories ${ }^{11}$ with recommended liability theories or alternative compensation systems:

1. Strict Liability and Intentional Tort Strategies-In some risk contexts, typical injurers consider the consequences of their actions and undertake informed cost-benefit assessments while typical victims do not, or vice versa. When a risk is "high-attention" for one type of party and "low-attention" for the other, hability should be imposed on the problem-solving category of actors. If this category consists of potential victims, "liability" simply means they must bear their own losses.

2. Contract and Negligence Strategies-In some risk contexts, both parties typically are knowledgeable and do consider accident losses, liability rules, and possible preventive measures. When a risk is "highattention" for typical mjurers and victims, the assignment of liability to either class of actors may affect the cost-benefit decisions of both. ${ }^{12}$ In these situations courts frequently cannot determine which party is in the best position to prevent accidents and spread losses. ${ }^{13}$ My analysis of this class of cases suggests that "high-attention" victims should generally bear or insure against their own losses unless a persuasive reason exists to shift them. Specifically, accident costs should be shifted only in response to unreasonable behavior by the "high-attention" injurer or a contractual right arising froin informed bargaining between the actors.

3. Risk-Related Insurance and Social Insurance Programs-In otller risk contexts, neither injurers nor victims ordinarily engage in informed problem-solving. In terms of social engineering effects, it is immaterial which category of actors could be the "cheapest cost avoiders" or which could best perform the cost-benefit analysis ${ }^{14}$ if neither category is likely to alter risk-avoidance decisions in response to the assignment of liability. When a risk is "low-attention" for typical parties, tort litigation is an expensive and uncertain vehicle for achieving

11. "High-attention" risk categories are those where at lease one category of actors engages in informed problem-solving behavior. See supra note 4; infra text accompanying notes 99-103.

12. See generally Coase, The Problem of Social Cost, 3 J.L. \& Econ. 1 (1960).

13. See infra notes $120-25,133-37$ and accompanying text.

14. See G. Calabresi, supra note 1, at 135-40, 261-63; Calabresi \& Hirschoff, Toward a Test for Strict Liability in Torts, 81 YaLE L.J. 1055, 1060-67 (1972); Posner, Strict Liability: A Comment, 2 J. Legal STUd. 205, 213-15 (1973). 
minimal behavior modification. In these situations the deterrence objective of liability rules is chimerical and loss spreading could be accomplished more efficiently through soine form of compulsory insurance system. $^{15}$

After a conceptual description of the liability system matrix, I present analytical sketches of prominent cases, including Vincent $v$. Lake Erie Transportation Co. ${ }^{16}$ Brown v. Kendall, ${ }^{17}$ Summers v. Tice, ${ }^{18}$ and Rylands v. Fletcher, ${ }^{19}$ in order to illustrate the value of applying different liability and compensation strategies in dissimilar risk contexts. The focus here on problein-solving ability and attention (or their absence) provides a useful paradigm for criticism of many existing hability rules and for support of soine controversial doctrines. The discussion in Part II also identifies the principal distimctions between my approach and tort theories advanced by other commentators, with particular emphasis on Dean Calabresi's strict liability test ${ }^{20}$ and on Professor Sugarman's advocacy in this Symposium of primary reliance on social insurance systems. $^{21}$

The scope of the analysis presented in this Article is ambitious, and no single essay, especially a Symposium contribution of limited length, could explore all ramifications and resolve all ambiguities associated with my approach. ${ }^{22}$ Nevertheless, the central theme should be clear: tort hability should be assigned whenever possible to categories of actors who do, in reality, think about accident prevention, loss spreading, and the effects of legal rules, and whose behavior may therefore be significantly influenced by potential hability. Many current hability doctrines diffuse responsibility for safety decisions and provide little incentive for "faultless" problem-solving actors to protect inattentive people against accident losses that regularly occur. If no problem-solving actor can be identified, or if hability rules impose losses on parties who do not engage

15. For a general comparison of social insurance and risk-related insurance systems, see infra notes 236-55 and accompanying text.

16. 109 Minn. 456, 124 N.W. 221 (1910); see infra notes 126-42 and accompanying text.

17. 60 Mass. (6 Cush.) 292 (1850); see infra text accompanying notes 236-38.

18. $33 \mathrm{Cal} .2 \mathrm{~d} 80,199$ P.2d 1 (1948); see infra notes 250-52 and accoinpanying text.

19. 3 L.R.-E. \& I. App. 330 (H.L. 1868); see infra notes 172-82 and accompanying text.

20. See Calabresi \& Hirschoff, supra note 14; Calabresi, supra note 3.

21. See Sugarman, Doing Away with Tort Law, 73 CaL1F. L. REv. 555 (1985).

22. I plan a series of essays over the next few years that will explore the relationship between probleın-solving behavior and selected torts issues, including the appropriate degrce of "strictness" in product liability law, the desirable treatment of inedical malpractice problems im light of the disparity in decisionmaking capabilities between medical professionals and patients, and the proper scope of proximate causation doctrines in problem-solving aceident contexts. Because my analysis falls largely within the frame of reference created by Dean Calabresi, I also intend to write an article that examines the differences between our liability theories. For a preliminary comparison of our approaches, see infra notes $115-25,134-43,178-80$ and accompanying text. 
in problem-solving, the social engineering goals of tort law will not be attained.

\section{I}

\section{ToRT IMPlications of Problem-Solving CONSTRAints}

Under the assumption of rational maximizing behavior, each person is expected to evaluate all opportunities and potential consequences in light of personal preferences. ${ }^{23}$ Yet people are confronted daily by a bewildering array of accident risks. Most occupations and many forms of recreation entail distinctive risks; all modes of transportation and sources of energy create significant hazards; food, water, and air may be contaminated by numerous toxic substances; every device and appliance may malfunction or be misused; every service may be improperly performed; even remaining in bed is not risk free. Risk avoidance, moreover, is only one realm of decisionmaking, and people must make many other kinds of choices in life. If limitations on information, comprehensional capacity, time, and attention are acknowledged, it follows that people cannot act as independent rational inaximizers for most decisions. Part I explores the implications for tort law of this behavioral proposition.

\section{A. Limits on Knowledge and Attention}

The degree of care individuals exercise in any situation depends on several variables, mcluding (1) their knowledge, which is a function of information, interpretive skills, and access to computational facilities, (2) their personality traits and inotivation levels, ${ }^{24}$ and (3) the competing demands for their time and attention. ${ }^{25}$ With respect to the adequacy of knowledge, some risk assessinents, such as those associated with exposure to toxic substances or latent product defects, require extensive technical data and specialized expertise. A person concerned with optimal avoidance of toxic health risks, for example, would need to understand which concentrations of which chemicals are present in which locations at which times, and what hazards are posed by those concentrations. ${ }^{26}$

23. See, e.g., R. PosNer, supra note 3, at 3-4, 12; Simon, supra note 6, at 2-3; Vickrey, Economic Rationality and Social Choice, 44 Soc. RESEARCH 691, 691 (1977).

24. See G. KATONA, supra note 8, at 218 ; R. MARKIN, supra note 8 , at 488 ; Simon, supra note 5, at 168. As one illustration of how motivation levels can affect patterns of behavior, some people frequently engage in comparison shopping; some people do so on an occasional basis; and other people hardly ever comparison shop. See Schwartz \& Wilde, Intervening in Markets on the Basis of Imperfect Information: A Legal and Economic Analysis, 127 U. PA. L. REv. 630, 637 (1979).

25. As one example, a person who understands safe driving practices perfectly may drive with reasonable care on some occasions and may be less attentive at different times if he is preoccupicd with professional, social, financial, or any other pressing concerns.

26. For discussions of the complexities and uncertainties associatcd with the estimation of toxic health hazards, see Latin, The "Significance" of Toxic Health Risks: An Essay on Legal Deci- 
Even Richard Posner and other adherents of the concept of rational maximizing behavior concede that individuals typically lack sufficient knowledge to assess some significant categories of risks. ${ }^{27}$ Indeed, the evidence suggests that people often misperceive the frequency or magnitude of obvious risks, such as those related to driving and smoking. ${ }^{28}$

Were inadequate knowledge the only major constraint on problemsolving ability, providing more information could appreciably improve the quality of risk-avoidance decisionmaking. ${ }^{29}$ There is, however, substantial evidence that people often do not properly use the information already at their disposal. ${ }^{30}$ Research on perception indicates that individuals tend to distort information, and hence analytical results, in response to prior expectations, desired outcomes, and socioeconomic affiliations. ${ }^{31}$ In contrast to Bayes' Rule, people do not always refine subjective probabihty estimates in light of new information. ${ }^{32}$ Information processing imposes a "cognitive strain" or "psychic tension" that may reduce people's ability and propensity to exarnme all facets of complex

sionmaking Under Uncertainty, 10 EcoLOGY L.Q. 339 (1982); McGarity, Substantive and Procedural Discretion in Administrative Resolution of Science Policy Questions: Regulating Carcinogens in EPA and OSHA, 67 GEO. L.J. 729 (1979).

27. See, e.g., R. POSNER, supra note 3, at 81-84, 136-37; Schwartz \& Wilde, supra note 5, at 1389-91, 1425-52. Schwartz and Wilde recognize that people may make mistaken product choices based on incomplete or inaccurate information; they assume, however, that consumers always attempt to balance product costs and benefits im light of whatever information they do have. If Schwartz and Wilde acknowledged that inherent contraints on time, attention, and cognitive capacity preclude people from independently assessing the risks associated with a multitude of possible product choices, they might be less sanguine about their conclusion that consumers on average seldom underestimate product risks. See id. at 1391, 1431-42, 1457-58.

28. See, e.g., Arnould \& Grabowski, Auto Safety Regulation: An Analysis of Market Failure, 12 BeLl J. Econ. 27, 34-35 (1981); Slovic, Fischhoff \& Lichtenstein, Facts Versus Fears: Understanding Perceived Risk, in Judgment Under UnCERTAINTY: HeURISTICS aNd Biases 463 (D. Kahneman, P. Slovic \& A. Tversky eds. 1982); see also Akerlof \& Dickens, The Economic Consequences of Cognitive Dissonance, 72 AM. ECON. REV. 307 (1982).

29. See S. Breyer, Regulation AND Its Reform, 161-64 (1982). But see Latin, Environmental Deregulation and Consumer Decisionmaking Under Uncertainty, 6 HARv. EnVTL. L. REv. $187,223-33$ (1982).

30. See R. MARKIN, supra note 8, at 494; Kahneman \& Tversky, Choices, Values, and Frames, 39 AM. Psychologist 341 (1984); Morgan, Multiple Motives, Group Decisions, Uncertainty, Ignorance, and Confusion: A Realistic Economics of the Consumer Requires Some Psychology, AM. ECON. Rev. Papers \& Proc., May 1978, at 58, 61; Simon, supra note 6, at 9-10. See generally the essays in JUDGMENT UNDER UNCERTAINTY: HEURISTICS AND BIASES, supra note 28.

31. See, e.g., K. ARrow, The Limits of Organization 75 (1974); Collier, The Sociological Foundations of Consumer Behavior. Their Implications for Economic Efficiency, 37 AM. J. ECON. Soc. 25, 28-29 (1978); Kahneman \& Tversky, On the Psychology of Prediction, in Judgment UNDER UNCERTAINTY: Heuristics AND BIASES, 48-68 (D. Kahneman, P. Slovik \& A. Tversky, eds. 1982).

32. See, e.g., Grether, Recent Psychological Studies of Behavior Under Uncertainty, AM. EcoN. Rev. PAPERS \& Proc., May 1978, at 70; Slovic, Fischhoff \& Lichtenstein, Behavioral Decision Theory, 28 ANN. REV. PSYCHOLOGY 1 (1977). 
problems. ${ }^{33}$ Once comprehensional capacity and attention span are exhausted, additional information may lead to "information overload" rather than to improved decisionmaking. ${ }^{34}$

Under the constraints of limited knowledge, time, attention, and comprehensional capacity, individuals frequently make choices without balancing costs and benefits im a meaningful way. Many forms of behavior are "programmed" or habitual, which means preestablished activity patterns are followed without any consideration of alternatives. ${ }^{35}$ Soine modes of behavior are imitative in the sense that choices are adopted largely because other people or groups have also selected them. ${ }^{36}$ In many settings, people employ highly simplified decisional criteria or "rules of thumb" to reduce decisionmaking costs, time requirements, and cognitive strain. ${ }^{37}$ Yet simplified decisional criteria often introduce biases that can distort computational results. ${ }^{38}$ People may also be subject to unpleasant "surprises"39 because they cannot estimate the probabilities of all possible outcomes and must therefore engage in experimental behavior. The net miport of these observations is that informed problem-solving behavior is a relatively infrequent phenomenon compared with the multitude of choices people must make. ${ }^{40}$ Thus, twentieth-century research on human cognitive processes contradicts the eighteenth-century supposition that people behave as rational maximizers for most of their choices. ${ }^{41}$

George Stigler recently expressed the "credo" of Chicago-school

33. See R. MARKIN, supra note 8, at 118; Green, Consumer Use of Information, in ON KNOWING THE CONSUMER 67 (J. Newman ed. 1966).

34. See, e.g., Lunn, Consumer Decision-Process Modcls, in MODELS OF BUyER BEHAVIOR 34, 51-52 (J. Sheth ed. 1974); Simon, supra note 6, at 13.

35. See, e.g., G. KATONA, supra note 8, at 218-19, 225; R. MARKIN, supra note 8, at 498; Reason, The Psychopathology of Everyday Slips, THE SCIENCES, Sept.-Oct. 1984, at 45.

36. See, e.g., G. KATONA, supra note 8, at 219; H. LIEBENSTEIN, BEYOND ECONOMIC MAN 45 (1976).

37. See, e.g., G. Katona, supra note 8, at 215, 218-19; Baumol \& Quandt, Rules of Thumb and Optimally Imperfect Decisions, 54 AM. ECON. REV. 23 (1964); Morgan, supra note 30, at 61.

38. See, e.g., Slovic, Toward Understanding and Improving Decisions, in 2 HuMaN PERFormance and Productivity: Information Processing and Decision Making 157, 159-65 (W. Howell \& E. Fleishman eds. 1982); Tversky \& Kahneman, Judgment Under Uncertainty: Heuristics and Biases, in JUDGMENT UNDER UNCERTAINTY: HEURISTICS AND BIASES, supra note 28, at 3. But see Einhorn \& Hogarth, Behavioral Decision Theory: Processes of Judgment and Clioice, 32 ANN. Rev. Psychology 53 (1981).

39. For a discussion of optimal behavior under conditions of possible "surprises," see Cohen \& Axelrod, Coping with Complexity: The Adaptive Value of Changing Utility, 74 AM. ECON. REV. 30, 31 (1984).

40. See G. KatonA, supra note 8, at 218; R. MARKIN, supra note 8, at 498. When people undertake problem-solving behavior, they may select decision criteria that require a less comprehensive analysis of alternative choices than would rational maximizing behavior. See, e.g., K. RADFord, Managerial Decision MaKing 64-65, 78 (1975) (minimize uncertainty rather than maximize returns); Simon, supra note 5, at 168-70 ("satisficing").

41. For another article criticizing "law and economics" commentaries because they have not 
economists as follows: "[P]eople act efficiently in their own interests. . . . [They] learn all the presently knowable things it pays them to know-always on average-and act with due regard for this knowledge."42 This Chicago-school conception is inconsistent with the research findings on cognitive limitations just cited, and it also conflicts with intuitions drawn from everyday experience that people frequently make mistaken choices. Human decisionmaking appears flawed, sometimes disastrous, from any "objective" viewpoint. The psychoanalytical literature, for example, describes decisions that are antithetical to the well-being and self-professed wishes of the subjects. ${ }^{43}$ The neghigence case law, so beloved of "law and economics" theorists such as Professors Coase and Landes and Judge Posner, is a veritable goldmine of "objectively" unreasonable behavior. ${ }^{44}$ Indeed, people usually regard their own decisionmaking processes as imperfect. They consider themselves inattentive at times; they often experience "surprises" because their probabilistic expectations turn out to be wrong; they may recognize uncertainty but not attempt to resolve it; they may have little confidence in the accuracy of their predictions; and they may conclude that their choices were mistakes once the consequences become evident. ${ }^{45}$ If inefficient behavior and uncertainty appear widespread, there is no reason to suppose that people ordinarily maximize personal utility on a conscious or unconscious level. ${ }^{46}$

acknowledged research findings from other social science disciplines, see Leff, Economic Analysis of Law: Some Realism About Nominalism, 60 VA. L. Rev. 451, 469.74 (1974).

42. Stigler, Economists and Public Policy, Regulation, May-June 1982, at 13, 16.

43. See, e.g., 6 S. Freud, The Standard Edition of the Complete Psychological Works OF Sigmund FreUd: THE PSYChopathology of EVERYDAY LIFE (J. Strachey ed. 1960); Reason, supra note 35; Goleman, Do "Freudian Slips" Betray a Darker, Hidden Meaning?, N.Y. Times, Nov. 27, 1984, at C1, col. 4.

44. I have never seen a plausible explanation by any adherent of rational maximizing behavior of why the common law reveals such a high incidence of "objectively" unreasonable deeisions.

45. No external seeond-guessing of the kind deplored by Chicago-school economists is required when people characterize their own decisionmaking as frequently suboptimal. It is anomalous that Chicago-school proponents, who in all other respects are champions of deference to individual judgments, should be unwilling to accept people's perceptions that their own choices often do not maximize their welfare.

46. Numerous "law and economics" analyses make behavioral assumptions that would be plausible only if people act as unconscious utility maximizers. See, e.g., Landes, Insurance, Liability, and Accidents: A Theoretical and Empirical Investigation of the Effect of No-Fault Accidents, 25 J.L. \& EcoN. 49 (1982) (no-fault insurance leads to higher accidents rates); Peltzman, The Effects of Automobile Safety Regulation, 83 J. POL. ECON. 677 (1975) (regulation imduces drivers to act with less care). But see O'Connell \& Levmore, A Reply to Landes: A Faulty Study of No-Fault's Effect on Fault?, 48 MO. L. REv. 649 (1983). The fact that some deeisionmaking undoubtedly occurs on the unconscious level in no way suggests that people can achieve optimal unconscious choices. Uuless the unconscious mind is omniscient, possesses infinite computational and attentional capacities, and is free from cognitive biases, unconscious decisioumaking could not possibly achieve maximizing results in all cases. To put it another way, there is no evidencc and no reason to presume that the unconscious mind is superhuman. 
Even if people know the risks associated with various forms of conduct, they may not understand the legal implications of that behavior. Judge Posner has noted that tort law must be "public" because secret rules cannot shape people's future actions. ${ }^{47}$ Yet liability rules must be more than merely knowable- they must be known, understood, and actively considered before they can affect behavior. Many liability doctrines are not comprehended by the general populace, and numerous classes of actors ordimarily do not modify their behavior in light of legal rules. The reasonably prudent child standard, for example, imposes liability if a child's actions fall below the norm established by children of similar age, maturity, and experience. ${ }^{48}$ In Vaughan v. Menlove, ${ }^{49}$ the court held that a person with bad judgment will be liable unless he conforins to the reasonable behavior of average people. ${ }^{50}$ In Breunig $v$. American Family Insurance Co., ${ }^{51}$ the court found an insane driver liable because a reasonably prudent (insane) person could have foreseen that her mental condition nright cause her to smash her car into an oncoming vehicle. ${ }^{52}$ Whatever the wisdom of these doctrines from the perspectives of "fairness" or judicial administration, they inake little sense in terms of social engineering. Children, msane people, and fools rarely adapt their risk-avoidance decisionmaking im response to legal rules. ${ }^{53}$ Many other categories of people simply do not understand the rules applicable to particular forins of conduct. Professor Epstem has contended, for example, that potential victims and injurers seldom understand whether strict liability or negligence doctrines apply in specific accident contexts. ${ }^{54}$

In many accident settings, hmited attention is a more serious constraint than inadequate knowledge. A recurring flaw in "law and economics" analyses is that they focus on behavior producing a particular accident, without recognizing that people may be exposed to numerous risks concurrently and have many possible choices competing for their

47. R. POSNER, Economic ANalysis of LAW 394 (1st ed. 1972). I did not find an explicit statement to this effect in the second edition of Posner's book, but it is implicit in any social engineering analysis.

48. See W. Keeton, D. Dobbs, R. Keeton \& D. Owen, Prosser and Keeton on the LAW OF TORTS 179-81 (5th ed. 1984) [hereinafter cited as PROSSER \& KEETON].

49. 3 Bing. (N.C.) 468, 132 Eng. Rep. 490 (1837).

50. Id.

51. 45 Wis. $2 d 536,173$ N.W.2d 619 (1970).

52. Id.

53. The argument is occasionally made that hability will induce the guardians of incompetents to exercise greater care, even if the incompetents themselves will not be influenced by legal rules. See, e.g., McGuire v. Almy, 297 Mass. 323, 327, 8 N.E.2d 760, 762 (1937). This social engineering objective could be promoted more directly by assigning losses to the guardians when their supervision is unreasonable; it is implausible that the imposition of liability on their wards will induce significant behavior modification by "reasonable" guardians.

54. See Epstem, The Social Consequences of Common Law Rules, 95 HARV. L. REv. 1717, 1744 (1982). 
limited attention. All individuals are subjected to a vast array of lowprobability risks, and psychological studies indicate that people frequently miscalculate those risks. ${ }^{55}$ Because any risk assessment makes demands on time, money, and psychological resources, people often do not consider low-frequency hazards even when catastrophic losses would occur if the risks materialize. In a study of disaster insurance coverage, for example, two social scientists concluded:

When asked about their insurance decisions, subjects in both the laboratory and survey studies indicated a disinclination to worry about lowprobability hazards. Such a strategy is understandable in view of the fact that limitations of people's time, energy, and attentional capacities create a "finite reservoir of concern." Unless we ignored nnany low-probability threats we would become so burdened that any sort of productive life would become impossible. ${ }^{56}$

It must be emphasized that attention to accident cost minimization requires the exercise of continuous attention while risky activities are performed. When people engage in repetitive actions over a prolonged time period, as with driving and many occupational operations, their attention often shifts to other subjects. Most people "know" that driving is dangerous and also "know" the driving practices necessary to achieve reasonable safety, but accidents happen because drivers do not pay sufficient attention during critical moments and therefore fail to adapt their behavior to changing circumstances. ${ }^{57}$ Vehicle operators can never anticipate exactly which moments will prove critical. Consequently, they cannot avoid these accidents unless they are continuously vigilant. And people do not, and cannot, remain alert at all times. Even if drivers are perfectly informed about traffic risks and corresponding liability rules, in the sense that they could correctly answer any question on those subjects, the imposition of liability will have little effect on accidents that result from periodic inattention.

Dean Calabresi presented another example of an accident that stems primarily from inattention. ${ }^{58}$ If a player negligently throws a ball into the stands and injures a spectator, the traditional doctrime of "assumption of risk" would insulate the injurer from hability. ${ }^{59}$ Calabresi cited this outcome as an instance where the courts regard one category of actors as best able to evaluate the activity's costs and benefits, even when only the other category is negligent. ${ }^{60}$ Whether or not spectators could

55. See, e.g., Slovic, Fischhoff \& Lichtenstein, supra note 28 , at 465-78.

56. Kunreuther \& Slovic, Economics, Psychology, and Protective Behavior, AM. Econ. REV. PAPERS \& Proc., May 1978, at 64, 67.

57. See generally Reason, supra note 35 , at 45 .

58. See Calabresi \& Hirschoff, supra note 14, at 1065.

59. See Prosser \& KeEton, supra note 48 , at $494-95$.

60. Dean Calabresi contended that: 
protect themselves from errant throws, many spectators do not devote continuous attention to on-field activities: they bask in the sun, carry on conversations, eat hot dogs, read scorecards, nap, or daydream. Even if most spectators understand the "assumption of risk" doctrine and know it applies to tlem, which is a fanciful premise, ${ }^{61}$ there is no reason to presume that any hability rule would have much effect on spectator behavior. This type of accident is caused by a lapse in attention, and continuous attention cannot be commanded by fiat or always be induced by pecumary incentives. Rather, given the plethora of risks to which people are exposed and the many competing deinands for their attention, mdividuals can devote close attention to soine risks only at the expense of mattention to others.

\section{B. Marginal Incentives for Accident Avoidance}

Calabresi's spectator hypotlietical illustrates another important reason why people do not always pay careful attention to liability rules. Tort liability doctrines only provide marginal incentives for behavior modification, and the incremental deterrent effects of potential liability are inconsequential im many accident contexts. It is implausible to assume that typical spectators will be significantly more vigilant if they realize they must bear their own losses because few people would regard an award of money damages, if it were available, as adequate coinpensation for severe pliysical injuries. ${ }^{62}$ The primary incentive for spectators to avoid being hit by balls is their desire to escape injury, and that incentive would exist regardless of the applicable liability rule.

It is also unlikely that imposition of liability on ballplayers would effectively deter these accidents. Players already have several nonlegal reasons to avoid making errant throws. They want to conform to professional norms of conduct; they want to avoid errors that may lose gaines, which would decrease their satisfaction and miglit affect future salaries; and they may lave ethical reasons for wanting not to hurt people.

[The assumption of risk doctrine] may even go to negate defendant's negligence, by expressing a judgment that although the defendant's conduct was not worth its costs (i.e., was negligent), the plaintiff was im a better position than the defendant to evaluate the costs and benefits involved (i.e., the plaintiff assumed the risk). . . . [A] spectator at a baseball game may be the best suited to evaluate the desirability of sitting in an unscreened bleecher given the likelihood of occasional negligent wild throws by the players during the game which may result in the spectator's being hit on the head (plaintiffs strict liability, or assumption of risk ... [T]he conclusion as to whether an accident cost should be shifted depends not on whether a party was neghgent, but rather on a judgment as to which party was in a better position to make the cost-benefit analysis irrespective of the other's negligence).

Calabresi \& Hirschoff, supra note 14, at 1065.

61. For a convoluted legal doctrine appheable to spectators at baseball games, see Davidoff $e x$. rel. Davidoff v. Metropohtan Baseball Club, Inc., 61 N.Y.2d 996, 463 N.E.2d 1219, 475 N.Y.S.2d 367 (1984). I criticize this doctrine infra text accoinpanying notes 183-98.

62. See G. CalabresI, supra note 1, at 216-25; Posner, supra note 14, at 214. 
Because the risk of serious harm to spectators is slight in comparison with the other incentives for good performance, tort hability for spectator injuries would provide at best a miniscule additional inducement for players to behave carefully. Most "law and economics" analyses assume there is always some category of actors whose behavior will be substantially influenced by the prospect of liability, but that premise is untrue for player/spectator accidents and in many other tort contexts. ${ }^{63}$

It is important to conipare the marginal deterrent effects of imposing accident costs on different categories of actors because at least two, and frequently more, categories could be assigned liability in any accident setting. Dean Calabresi recently contrasted four prototypical liability strategies that may be apphied to automobile accident losses. $\mathrm{He}$ noted that social imsurance systems provide no private incentive for accident avoidance because losses are borne by society as a whole. ${ }^{64}$ Thirdparty liability systems create an incentive for drivers to protect the occupants of other cars, but not to protect themselves and their passengers. ${ }^{65}$ First-party systems create an incentive for drivers to protect theniselves, but not people in other vehicles. ${ }^{66}$ Strict product liability creates an incentive for manufacturers to reduce both occupant and third-party losses, but product liability does not induce drivers to operate vehicles safely. ${ }^{67}$ Thus, Calabresi contended that each potential hability system provides incomplete incentives for accident cost minimization.

Although this conclusion is undoubtedly correct on a conceptual plane, Calabresi's essay provided little insight on the relative magnitude of the incentives created by each liability strategy. He acknowledged that first-party and third-party systems may achieve similar deterrent effects because the actions drivers take to protect themselves are substantially the same as those necessary to protect other people. ${ }^{68}$ From a social engineering perspective, the critical question posed by Calabresi was whether accidents are "more cheaply reduced by making better cars or by inducing better drivers." 69 He then noted his inclination "to prefer first-party over third-party or product liability plans."70 Although he justified this conclusion largely on distributional grounds, ${ }^{71}$ the implica-

63. For other examples, see infra text accompanying notes 237-38, 250-52, 271.

64. Calabresi, First Party, Third Party, and Product Liability Systems: Can Economic Analysis of Law Tell Us Anything About Them?, 69 Iowa L. REv. 833, 838, 840 (1984).

65. See id. at 837. Calabresi discussed first-party imsurance systems primarily from the perspective of an "owner-driver," see id.; but only owners are required to insure and their insurance rates may not reflect occasional vehicle use by a high-risk or low-risk driver.

66. See id. at 836-37, 846-47.

67. See id. at $837,841,846$.

68. Id. at 847 n.39.

69. Id. at 842 .

70. Id. at 847 ; see id. at 842 .

71. See id. at $842-50$. Calabresi correctly observed that the current, predominantly third-party 
tion was that first-party hability would achieve as good or better deterrence than the competing hability approaches. ${ }^{72}$

Calabresi's analysis included virtually no discussion of the marginal mcentives created by different liability rules. Even if vehicle operation is a more significant determinant of accident losses than vehicle design, it cannot simply be assumed that legal attempts to induce better driving through assignment of liability to drivers will prove more efficient than legal strategies that encourage safer cars. Drivers already have several powerful reasons to prevent accidents regardless of the applicable liabil-

approach discriminates against poor or old drivers who have below-average expected losses because insurance rates are based on average losses. He assuined, however, that first-party insurance rates would be tailored to the expected losses of different classes of drivers and inay therefore be preferable from a distributional perspective. There are several problems with this assuinption. For one thing, first-party rates inay also be based on average losses rather than tailored to expected losses. Indeed, this is the current practice for the first-party component of "no fault" insurance plans. Second, for insurance companies to charge poor people lower premiuns based on lower expected losses, they would have to recompute each policyholder's wealth and economic prospects each year. I doubt that would be feasible. Third, tailored first-party rates would depend on accident propensities as well as expected losses, and some of the groups that Calabresi believes will be helped by a shift to first-party systeins-the aged, the young, and possibly the poor who eannot afford to purchase or adequately inaintain safer cars-will continue to have relatively high insurance rates because they have high accident experiences. Finally, because insurance operates on the basis of vehicle ownership, rather than with separate policies for each driver, insurance companies will tend to average expected losses to take into account situations where young and iniddle-aged drivers use the samc car. Young and poor drivers inay also be likely to have inore occupants in the car than other classes of "owner-drivers."

Moreover, I do not believe distributional consequences can be considered wholly apart from the efficiency gains associated with accident cost reduction under different systems. If a product liability treatment would induce manufacturers to develop and install safety equipment, and would therefore substantially decrease net accident losses, the absolute economic burden imposed on poor "ownerdrivers" may be reduced even if their relative position is not as advantageous as it would be under a first-party system. I believe circumstances exist in which some degree of net social efficiency should be sacrificed to prevent unfair distributional consequences, but those are generally situations where a social maximizing choice would inake disadvantaged groups worse off than they previously were. If installation of feasible safety devices by manufacturers would significantly reduce net accident costs, which I think is true, then all classes of "owner-drivers" may be better off under manufacturer hability than under a first-party insurancc system, even if some benefit more than others.

72. See id. at $841-43$. Calabresi hypothesized:

[W]ere the dominant system of accident law a first party one we would not be arguing about the relative inerits of requiring seat belts or air bags, nor about the crash-worthiness of the car in which we ride. Insurancc rates would give a fair clue to the cost effectiveness of each of these.

Id. at 838-39 (footnote omitted). I do not find this assumption credible. For example, heavy full-sizc automobiles are safer for their occupants than subcompact cars, but they are correspondingly more dangerous for the occupants of other cars when a collision occurs. Yet third-party insurance systems rarely impose a premium for larger vehicles that are more dangerous to third parties, and "no fault" plans offer no discount for larger vehicles that afford occupants more protection in crashes. Moreover, a product hability system would inducc manufacturers to devise additional safety measures, but first-party insurance rates could not refiect as-yet-undeveloped safety equipment. I believe product liability would provide a greater incentive than first-party insurance or any driver liability system for manufacturers to undertake research and development programs. See infra notes 73-83 and accompanying text. 
ity rule, including their desires to avoid death or personal injury, anxiety for relatives and friends, interference with existing plans and schedules, injury to other people, the risk of inadequate compensation for their losses through the tort system, and the inconveniences, delays, and uncertainties generally associated with tort litigation. Vehicle inanufacturers also have soine private incentives to reduce accidents, ${ }^{73}$ but absent legal liability for accident losses, the inanufacturers' incentives to install safety equipinent generally inay not outweigh their incentives to reduce vehicle production costs and sales prices. ${ }^{74}$ If drivers have stronger motivations to avoid accidents than do inanufacturers in the absence of legal hability, then imposition of product hability inay induce greater accident-avoidance behavior with resulting reductions in accident losses than would any driver hability systein. ${ }^{75}$

This is inore than a inere possibility. In the past decade, approximately one hundred thousand deaths and a million injuries could have been prevented by the widespread installation of airbags or equivalent passive restraint technology. ${ }^{76}$ The effectiveness of airbags was amply deinonstrated years ago, and the cost of this safety equipinent would have been less than the losses resulting froin preventable deaths and injuries. ${ }^{77}$ The cost of airbags, however, would visibly increase vehicle prices whereas accident losses are currently absorbed by victims or spread diffusely through a variety of insurance systeins. ${ }^{78}$ Despite the ability of airbags to reduce net accident costs, the Supreine Court recently observed that the automobile industry has "waged the regulatory equivalent of war against the airbag."79 A shift from driver liability to product liability would inake manufacturers responsible for billions of dollars of accident losses and would therefore create a strong inarginal incentive for thein to install various safety features that they beheve

73. These include competitive advantages in attracting consumers who value safety, a desire to promote repeat purchases by customers, and professional satisfaction in creating safe products.

74. As Calabresi noted, automobile manufacturers have concluded under the prevailing driver liability system that "safety does not pay." Calabresi, supra note 64, at 838 n.20.

75. Although imposition of liability on drivers would seldom change their overt risk-avoidance behavior, first-party insurance might decrease the level of driving by especially risky classes if rates are tailored to different accident propensities and expected losses. See id. at 839 n.23, But see infra notes 210-22 and accompanying text. Yet, Calabresi acknowledged that his distinction between firstparty and third-party insurance systems "may be just an illusion" from the perspective of accident deterrencc. Id. at 843; see also id. at 847 n.39.

76. See Motor Vehicle Mfrs. Ass'n of the United States v. State Farm Mut. Ins. Co., 103 S. Ct. 2856, 2862, 2864 (1983); 42 Fed. Reg. 34,289-90, 34,298 (1977).

77. See 42 Fed. Reg. 34,289-90, 34,298-99 (1977); NAtional Highway TRAFFic SAFETY Admin., Automobile Occupant Crash Protection, Progress Report No. 3, at 4 (1980).

78. Aside from third-party and "no fault" insurance plans, automobile accident costs are partly distributed through life insurance, private health imsurance, public health and disability imsurance, employee benefits programs, and self-insurance by commercial enterprises.

79. Motor Vehicle Mfrs. Ass'n of the United States v. State Farm Mut. Ins. Co., 103 S. Ct. 2856, 2870 (1983). 
would be less expensive than the tort damages associated with avoidable injuries.

Legal incentives should be tailored whenever possible to the specific conduct responsible for large accident losses. If traffic accidents stem primarily from lack of continuous attention rather than from inadequate knowledge or dehiberately careless driver behavior, we should evaluate competing liability systems in terms of their propensity to minimize accident losses that result from periodic inattention. Calabresi recognized that product liability will induce manufacturers to install cost-justified safety equipment, ${ }^{80}$ and this equipment would function continuously to reduce the incidence or severity of accidents. ${ }^{81}$ Indeed, a major purpose of safety devices is to protect vehicle occupants against the consequences of improper vehicle operation. A shift from third-party liability to firstparty liability is less likely to minimize accident losses that stem from inattention than would a shift from any driver liability system to manufacturer hability. Imposition of strict product liability for motor vehicle accidents would pose serious implementation problems that are outside the scope of this Article. ${ }^{82}$ Nevertheless, it appears unlikely that any realistic driver liability system could provide marginal incentives for accident cost mimimization that would be as effective as those under manufacturer liability. ${ }^{83}$

In sum, the assumption that liability rules influence most people's risk-avoidance behavior in most accident contexts is unproven and appears unwarranted. In many settings, people lack sufficient information and expertise to assess risks properly; they are inattentive to known risks; they do not understand the apphicable liability doctrines; and compelling nonlegal mcentives shape their behavior. All that tort liability can achieve by itself is the imposition of additional costs on a specified category of actors. If designated categories of actors do not adapt their choices to changing circumstances, risks, and legal rules, which requires

80. See Calabresi, supra note 64 , at 837,839 .

81. Better braking and steering systems would enable improved renctions to risky situations and may therefore reduce aceidents that result from momentary inattention. Stronger vehicle frameworks and airbags or other passive restraints would reduce the average level of damages in crashes that occur. These safety features operate on a continuous basis to protect drivers against their own occasional lack of care and against other people's risky driving behavior.

82. There would be boundary-drawing problems, such as whether losses associated with drunk driving should be imposed on automobile manufacturers, and also transitional problems, such as the difficulty of handling used car markets when initial vehicle prices did not include an insurance premium for projeeted losses. There would also be possible distributional problems if currently subsidized groups of high-risk drivers do not receive comparable subsidies when they purchase vehicles. I intend to address some of these problems in a future essay devoted to strict product liability and problem-solving behavior by manufacturers.

83. See infra notes $210-22$ and accompanying text. 
some degree of problem-solving ability and attention, ${ }^{84}$ assignment of tort liability will seldom promote social engineering goals. When neither potential injurers nor victims imdependently assess costs and benefits, hability rules have distributive effects but do not significantly affect accident costs. On the other hand, in some accident contexts one or more parties ordinarily do engage in problem solving for specific types of risks and would be significantly influenced by the imposition of liability. These are areas where tort liability can provide incentives for efficient cost minimization and loss spreading. "Law and economics" analyses have customarily failed to distinguish between situations where liability serves as an effective deterrent and the many cases where liability will not alter riskavoidance behavior.

\section{Specialization and Adaptive Behavior}

The capacity for informed problem solving varies widely among individuals, but there are certain accident contexts in which tort liabihty may induce a relatively high level of cost-minimization decisionmaking. Those settings feature decisionmakers who are able to specialize in limited problem elements, are able to adapt their decisions in response to experience derived from many smilar choices, and are subject to performance monitoring systems that aim to control pecuniary costs including potential tort damages. These problem-solving attributes are especially prevalent in organizational, commercial, and professional settings, which ineans that the imposition of accident losses on problemsolving actors would often lead to an expansion of enterprise hability. Many torts analysts have argued that businesses should be responsible for accident costs arising from their nonnegligent activities, but the following discussion emphasizes decisionmaking characteristics rather than the conventional rationales for enterprise hability.

Influential theorists such as Kenneth Arrow, Herbert Simon, and Oliver Williamson have stressed the importance of specialization as a central characteristic of organizational decisionmaking. ${ }^{85}$ No individual could examine all facets of complex problems because of inherent constraints on problem-solving ability ${ }^{86}$ but specialization enables organizations to assign confined and therefore nianageable issues to different agents on the basis of comparative advantages. Precisely because specialists focus their professional attention on a limited set of subjects, they are

84. Adaptation based on feedback from prior experiences is a central characteristic of problemsolving behavior. See infra text accompanying notes 91-93.

85. See, e.g., K. ARROW, supra note 31, at 39, 53; O. WILlIAMSON, supra note 6, at 133-36; Simon, Rational Decision Making in Business Organizations, 69 AM. ECON. REV. 493, 501 (1979).

86. See, e.g., Hurwicz, The Design of Resource Allocation Mechanisms, in STUdIES IN Resource allocation Processes 3, 7 (K. Arrow \& L. Hurwicz eds. 1977); Simon, supra note 6, at 12-13. 
generally better able than average people to acquire relevant information and expertise. Product designers, bank trust officers, and airplane pilots, for example, may be no more careful than other people when they drive, mow their lawns, or attend baseball games, but they normally can be expected to behave with a greater-than-average degree of competency when making decisions within their areas of expertise. The benefits of specialization do not necessarily require an extensive technical background; many activities entail "learning curves" that arise from increasing familiarity with recurring problems. ${ }^{87}$ Moreover, information collection and use exhibit increasing returns to scale. ${ }^{88}$ This means it is frequently more efficient for one person to make a thousand similar decisions than for a thousand decentralized actors each to make that kind of decision once. ${ }^{89}$ Economists have long recognized the value of economies of scale and division of decisionmaking responsibilities in production activities. The same types of advantages would often accrue from specialization in accident cost-minimization decisionmaking.

Organizations employ numerous mechanisms to focus the attention of agents on institutional goals and to improve the quality of their decisions: these strategies include managerial supervision, selective hiring criteria, rewards for superior performance, competition between agents with sinvilar functions, peer pressure in teant operations, intra-firm and trade association newsletters that highlight iniportant developments, trainimg courses and conferences on topical issues. Such mechanisms do not assure perfect correspondence between organizational objectives and agent behavior, ${ }^{90}$ but they are nonetheless often effective in directing institutional decisionmakers toward salient opportunities and costs. There are few comparable mechanisms that could focus the attention of average consumers or other nonspecialists on significant accident losses, and no individual could devote continuous attention to all personally relevant risks.

Decision theorists also stress the central role experiential learning plays in the selection of efficient choices. ${ }^{91}$ Professor Simon, for example,

87. See Arrow, The Economic Implications of Learning By Doing, 29 REv. EcoN. STuD. 155 (1962).

88. See, e.g., K. ARRow, supra note 31, at 33, 38-39; Wilson, Informational Economies of Scale, 6 BELL. J. ECON. 184 (1975).

89. See, e.g., K. ARROW, supra note 31, at 39, 68-69; O. WILlIAMSON, supra note 6, at 51; Zeckhauser, Uncertainty and the Need for Collective Action, in PUBLIC EXPENDITURES AND POLICY ANALYSIS 96, 114 (R. Haveman \& J. Margolis eds. 1970).

90. The inability of organizations to ensure optimal behavior by agents is frequently described as the "span of control" problem. See O. Williamson, supra note 6, at 133-35, 142-44.

91. See, e.g., Boulding, The Economics of Knowledge and the Knowledge of Economics, in EcoNOMICS OF INFORMATION AND KNOWLEDGE 21, 28 (D. Lamberton ed. 1971); Lunn, supra note 34, at 42-46; Cyert \& DeGroot, Rational Expectations and Bayesian Analysis, 82 J. PoL. EcoN. 521, 523-24 (1974). 
observed that "learning in the form of reaction to perceived consequences is the dominant way in which rationality exhibits itself."92 Organizational and cominercial actors frequently can adapt their behavior in response to feedback from many similar choices, and consequently can develop actuarial histories that enable informed cost-minimization and loss-spreading decisions. ${ }^{93}$ Specialists in risk-creating activities are generally more likely than other people to receive meaningful feedback on the losses associated with those activities and on the utility of possible preventive measures. In contexts where accident risks cannot yet be defined with reasonable precision, speciahists are usually better able to refine probability estimates when new information becoines available because they regularly monitor developments in their fields of interest. The import of these observations is that specialization facilitates behavioral adaptation on the basis of prior experience and recognition of changing circumstances.

In addition, average people frequently pay little marginal attention to liability doctrines that entail money damages because they do not assess the cost of physical, emotional, or reputational injuries predominantly in economic terms. In contrast, coinmercial enterprises and many other organizations have well-developed budgetary processes that direct attention to accident costs if the firms are liable for those losses. This degree of cost-consciousness has precisely the opposite effect when firms are not held liable for losses resulting from their activities. Price coinpetition ainong businesses may, for example, induce a well-intentioned firm to pollute if its competitors derive production advantages from pollution without corresponding liability for the social costs of their emissions; ${ }^{94}$ and inexpensive but unsafe goods may gain a competitive advantage over more reliable products if manufacturers are not liable for product-related losses and if typical consumers cannot differentiate between relatively safe and risky cominodities. ${ }^{95}$ The point here is that the imposition of tort liability, with its pecuniary consequences, is more likely to influence the behavior of decisionmakers who systematically pay attention to economic costs, and that attribute is inore prevalent in organizational and cominercial activities than in most other settings.

"Law and economics" commentaries occasionally concede that average people are uninformed in inany accident settings, but these analyses nonetheless maintain that deterrent incentives are important at the

92. Simon, supra note 6 , at 8 .

93. See, e.g., Schwartz \& Wilde, supra note 5, at 1445-46.

94. See, e.g., Kapp, Environment and Technology: New Frontiers for the Social and Natural Sciences, 11 J. ECON. Issues 527, 532 (1977); Latin, supra note 29, at 211.

95. See, e.g., Akerlof, The Market for "Lemons": Quality Uncertainty and the Market Mechanism, 84 Q.J. ECON. 488 (1970); Spence, Consumer Misperceptions, Product Failure and Producer Liability, 44 Rev. ECON. STUD. 561 (1977). 
margin. ${ }^{96}$ Under this view, imposing liability may be worthwhile if it influences some people's risk-avoidance decisions even when it would not affect the behavior of typical actors. Although liability or compulsory insurance always may provide some additional deterrence, litigation is an expensive way to allocate accident losses and the transaction costs associated with the tort system often exceed the efficiency gains resulting from mfrequent marginal deterrence. An empirical judgment must be made on whether the benefits from margimal deterrence in a few "low-attention" cases justifies requiring litigation in all cases of the same type. Yet we have ample evidence about the high costs of the torts system, while the deterrent value of legal rules is speculative in risk contexts where typical parties are not effective problem solvers.

Moreover, any liabihity doctrine that allocates losses to one category of actors necessarily dilutes the marginal risk-avoidance incentives of other actors. A neghigence standard, for example, increases the incentives for victims to protect themselves against "reasonable" risks, but only at the cost of reducing the incentive for injurers to protect victims against those risks. ${ }^{97}$ Thus, imposition of tort hability on one class of actors cannot be rationalized on a marginal deterrence argument without considering its marginal effects on the other parties' risk-avoidance decisionmaking. ${ }^{98}$ Once we recognize that no one can learn everything and that different people pay attention to different types of loss-creating activities, it may be sensible for society to assign tort liability to the categories of actors that can effectively assess and minimize specific accident risks. The central social policy question is not whether average people could conceivably make cost-mimmizing decisions. Rather, the issue is whether they really will do so in specific accident contexts, and whether their judgments will be as efficient as the precautionary decisions that specialists in risk assessment would render when they are liable for accident losses.

\section{II}

\section{The Liability System MATRIX}

In Part II, I contend that diverse liability and compensation strategies will be more or less effective in achieving social engineering tort

96. See, e.g., Priest, $A$ Theory of the Consumer Product Warranty, 90 YALE L.J. 1297, 1347, 1350 (1981).

97. See generally Calabresi \& Hirschoff, supra note 14, at 1056-59. In theory, we would not want injurers to protect victims against "reasonable" risks. In practice, the determination of which risks are "reasonable" is often very difficult, and a strict liability rule would reduce the uncertainty about where losses will be allocated.

98. This is an extremely important point that Calabresi does not, in my opinion, properly evaluate in his comparative discussion of systems for reducing and allocating automobile accident costs. See supra text accompanying notes 64-83; infra text accompanying notes 210-22. 
goals depending on the characteristic behavior of actors in different risk contexts. There is no reason, for example, to expect a liability system that functions efficiently when both categories of actors are capable problem solvers to perform comparably well when both categories ordinarily do not pay attention to a specific risk and the corresponding legal rules. The policies that support matching particular kinds of risks with different liability and compensation systems, based on the problem-solving characteristics of classes of parties, are described here on a conceptual plane and then are further developed through analytical critiques of illustrative tort doctrines.

The following inatrix depicts the proposed arrangement of risk categories and corresponding tort liability or alteruative compensation systems:

FIGURE 1

\begin{tabular}{l|l|l|}
\multicolumn{1}{c}{} & \multicolumn{1}{c}{$\begin{array}{c}\text { High-Attention } \\
\text { Risks for } \\
\text { Injurers }\end{array}$} & \multicolumn{1}{c}{$\begin{array}{c}\text { Low-Attention } \\
\text { Risks for } \\
\text { Injurers }\end{array}$} \\
\cline { 2 - 3 } $\begin{array}{l}\text { High-Attention } \\
\text { Risks for } \\
\text { Victims }\end{array}$ & $\begin{array}{l}\text { Negligence or } \\
\text { Contractual Rights }\end{array}$ & $\begin{array}{l}\text { Victim Bears } \\
\text { Own Loss }\end{array}$ \\
$\begin{array}{l}\text { Low-Attention } \\
\text { Risks for } \\
\text { Victims }\end{array}$ & $\begin{array}{l}\text { Strict Liability } \\
\text { (or Intentional } \\
\text { Tort Liability) } \\
\text { on Injurers }\end{array}$ & $\begin{array}{l}\text { Risk-Related or } \\
\text { Social Insurance } \\
\text { Systems }\end{array}$ \\
\hline
\end{tabular}

Under this loss-allocation inatrix, judges or legislators must determine whether different classes of parties should be characterized as "high-attention" problem solvers with respect to particular types of risks. The term "high-attention risk" is used to denote an accident context in which a category of actors meets all of the requirements for effective costminimizing decisionmaking: typical actors must understand material risks and applicable liability doctrines, must pay attention to risks and legal rules while engaged in risky conduct, and must assess the costs and benefits of alternative choices when subject to liability for a designated type of accident loss. ${ }^{99}$ If any of these conditions is absent in a given accident setting, the risk should be characterized as "Iow-attention." The required delineations between types of risks will present boundarydrawing problems in some cases, but these determinations should be no more difficult than the line drawing necessary under other tort

99. See supra text accompanying note 4 . 
theories. ${ }^{100}$

A specified risk may be "high-attention" for one class of actors and "low-attention" for others because different people respond differently to particular hazards. This determination must be made on an "objective" basis in the sense that it apphies to a class of comparably situated actors and does not require an inquiry into the subjective mental processes of each individual. As noted in Vaughan v. Menlove, ${ }^{101}$ a subjective test would not be judicially administerable. ${ }^{102}$ Moreover, Dean Calabresi observed that inost people are covered by sonie form of insurance, which means hability losses are spread across the class of those insured and the corresponding deterrence incentives function on a categorical level. ${ }^{103}$ The social engineering purpose of tort liability is to induce similar actors to undertake efficient cost-nimimizing behavior in the future; past losses obviously cannot be avoided. Thus, assignment of liability will proniote social engineering goals only to the extent that the class of problem-solving actors modifies precautionary decisions in response to legal rules.

\section{A. Loss Internalization and Problem-Solving Risks}

Many torts analysts contend that accident losses should be interualized on the activities and actors that cause them. This conception has increasingly come under attack froin botl the "right" and the "left." Proponents of rational inaximizing behavior assume that liability influences the risk-avoidance choices of all actors at the margin, which would inake it impossible to identify in advance the activities on which costs should be internalized in order to create optimal incentives for deterrence. ${ }^{104}$ George Priest, for example, argues that courts generally cannot determine whether product-related losses should be interualized by manufacturers, consumers, or some other seginent of society. ${ }^{105}$ In contrast, advocates of social insurance systems contend that tort litigation and resulting loss internalizations cannot achieve optimal levels of compensa-

100. For a discussion of boundary-drawing problems associated with several tort theories, see infra text accompanying notes 273-79.

101. 3 Bing. (N.C.) 468, 132 Eng. Rep. 490 (1837).

102. See id.; Prosser \& KEETON, supra note 48, at 176-78; see also Canterbury v. Spence, 464 F.2d 772, 780 n.15, 787-88 (D.C. Cir. 1972), cert. denied, 409 U.S. 1064 (1973).

103. See Calabresi \& Hirschoff, supra note 14 , at $1069-70$ \& n.54, 1075.

104. This was the point of Coase's famous critique of Pigou's externality analysis: incompatible resource uses create reciprocal interferences, which means it would be arbitrary to single out one use as the activity that should be curtailed through imposition of an externality tax. See Coase, supra note 12, at 28-42; see also Posner, supra note 14, at 208-09.

105. Professor Priest has not yet published the essay in whiclı he intends to develop this point fully, but it is cited in the most recent report of the Yale Civil Liability Program. See Yale Law School Civil Liabihty Program, 1983 Annual Report 38. The same theme is inplicit in his "investment theory" argument that producer and consumer efforts to achieve safety can be substituted at the margin. See Priest, supra note 96, at 1311-13, 1351; Priest, Punitive Damages and Enterprise Liability, 56 S. CAL. L. REV. 123, 123-27 (1982). 
tion. Professor Sugarman, for example, argues that liability seldom promotes either deterrence or efficient loss spreading, which means the selection of specific activities on which to internalize costs would generally involve arbitrary judgments. ${ }^{106}$

The approach to internatization recommended here entails a hierarchical treatment based on the premise that tort liability may encourage accident deterrence in problem-solving risk contexts but not in others. Most analysts would agree that loss avoidance is preferable to loss spreading in cases where accident costs exceed prevention costs and where specified parties can be induced to adopt efficient precautionary measures. ${ }^{107}$ Internalization should be regarded as a device to create incentives for problem-solving actors to undertake cost-minimization decisionmaking. Under this instrumental approach, the assignment of liability would turn on the decisionmaking characteristics of the parties rather than on any metaphysical causal distinction. ${ }^{108}$ If a typical "causer" in a given accident setting is not a knowledgeable problem solver, the imposition of tort hability is unlikely to induce cost-minimizing behavior.

Internalization of losses may decrease accident costs in two dissimilar ways. Imposition of losses on categories of problem-solving actors would induce them to prevent accidents when the costs of precaution are less than the costs of mjuries and to refrain from activities when the costs of both precaution and insurance exceed the marginal value of those activities. In other words, internatization of losses on problem-solving actors would directly influence their risk-avoidance decisions. In contrast, internalization on "low-attention" parties would raise the costs of the underlying activities and may therefore induce some people to decrease their level of participation in risky activities. Because people often pay attention to prices in settings where they do not understand or pay attention to specific accident risks, internalization of losses on "lowattention" categories of actors could change their price-avoidance deci-

106. See Sugarman, supra note 21 , at 559-91.

107. Professor Sugarman may, however, beheve that the principle of "horizontal equity" should take preccdence over the goal of efficient accident cost reduction. See id. at 603-09. He did not address the relative importance of deterrence and equal compensation for all similar injuries because of his insistencc that tort law achieves little or no effective deterrence. Dean Calabresi's discussion of distributional considerations in the context of automobile accident costs suggests that he would be willing to forego some efficiency to prevent unfair distributive effects, but his analysis provided little guidance on how deterrent and distributional consequences may be balanced against each other when these goals conflict. See Calabresi, supra note 64, at 842-50; see also supra note 71 .

108. I agree with Calabresi and Coase that assignment of liability on a "causation" basis often requires arbitrary distinctions or imphicit normative judgments between activities that contribute to accident losses. See G. CALABresI, supra note 1, at 6-7 n.8, 131-99; Calabresi, Concerning Cause and the Law of Torts: An Essay for Harry Kalven, Jr., 43 U. CHI. L. REv. 69 (1975); Coase, supra note 12. 
sions and consequently may lead to reduced accident costs. In recognition of these possible price effects, I argue below that internalization of losses through risk-related insurance programs may be preferable to reliance on social insurance in unusually dangerous "low-attention" risk contexts. ${ }^{109}$ Nevertheless, under my hierarchical approach accident costs should be internalized on categories of problem-solving actors rather than on "low-attention" actors whenever problem-solving behavior is a substantial contributing cause of accident losses. ${ }^{110}$

From the perspective of long-run accident deterrence, I believe problem-solving actors would generally find ways to reduce losses when precaution is feasible or would raise the prices of risky activities, and consequently would induce price-avoidance behavior by other classes of actors. $^{111}$ From the perspective of administerability, courts and legislatures can identify categories of problem-solving actors more reliably than they can assess the elements necessary to compare the deterrent effects of risk-avoidance and price-avoidance behavior. These eleinents include the potential price increases associated with alternative loss allocations, the degrees of price-elasticity associated with alternative activities, and the relative safety of substitute activities. ${ }^{112}$ Thus, the proposed hierarchical

109. See infra text accompanying notes 239-55. From the perspective of accident cost minimization, a comparative judgment is required between the greater marginal deterrent effects of riskrelated insurance im high-frequency, high-severity accident contexts and the typically lower transaction costs associated with social msurance programs.

110. I intend to discuss the relationship between problem-solving behavior and "legal causation" in a future essay. For purposes of the analysis in this Article, the requirement that problemsolving behavior must be a "substantial contributimg cause" of accident losses simply adopts the traditional tort law assumption that costs should not be imposed on parties unless their actions significantly, though not wholly, created the relevant accidents. In this sense, the requirement of "legal causation" is used to circumscribe the boundaries of liability rather than to define the legal criteria under which liability will be imposed. See Calabresi, supra note 108, at 78-79, 84-85.

111. Internalization of accident losses on a particular activity will generally raise its price and may consequently mduce some price-avoidancc behavior. Development and implementation of improved safety measures would increase the cost of a designated activity; first-party insurance against accident losses would also increase activity costs, but potentially by a greater or lesser amount than would investınents in marginal safety measures. Some entity-whether legislatures, courts, regulatory agencies, decentralized problem-solving actors, or deccntralized "low attention" actors-inust make the fundamental decision whether to prevent or insure against losses in particular accident contexts. This choice requires an ability to estimate the likely payoff from safety-related research and developinent efforts, the likely implementation costs of new safety ineasures in comparison with the additional precaution achieved, and the likely pricc-avoidance effects if loss-spreading insurance is employed instead of investments in accident prevention. I believe decentralized problein-solving actors generally possess better information and expertise than other potential decisionmaking entities, and internalization of accident losses on categories of problein-solving actors would induce thein to make these kinds of choices. Calabresi has often inade the same type of argument. See Calabresi, supra note 3, at 669-70; Calabresi \& Hirschoff, supra note 14, at 1060-61, 1074-76; Calabresi, Torts-The Law of the Mixed Society, 56 TEXAS L. REv. 519, 528 (1978). Yet his recent treatment of automobile accident losses appears incompatible with this position. See supra text accompanying notes $64-83,98$; infra text accoinpanying notes $210-22$.

112. A legislative or judicial decision to internalize accident costs on a class of "low-attention" 
treatment presumes that the social engineering function of loss internalization is, first, to encourage accident cost reduction directly through risk-avoidance decisionmaking by problem-solving actors, and, only when explicit accident prevention is unlikely, then to encourage accident reduction indirectly through price-avoidance behavior. ${ }^{113}$

The term "unilateral problem solving" is used in this Article to denote accident settings in which only one category of actors, either potential injurers or victims, meets all of the requirements for efficient cost-minimization decisionmaking. The term "bilateral problem solving" denotes accident settings in which both parties typically are proficient decisionmakers. In bilateral problem-solving contexts, there is no $a$ priori reason to assume that injurers are cheaper cost avoiders than victims or vice versa. Because problem-solving victims can anticipate and insure against accidents, losses should be internalized on victim activities unless there is a compelling rationale for shifting them. ${ }^{144}$ In unilateral problem-solving contexts, internalization on the problem-solving actors will promote efficient risk-avoidance and insurance decisions, while internalization on "low-attention" parties would at best achieve only loss spreading and some price-avoidance behavior. At the lowest level of the hierarchy, in "low-attention" risk contexts where neither victims nor injurers typically are informed problem solvers, the value of legal attempts at internalization is more questionable. These loss allocation strategies are reffected in the liability system matrix, which indicates that a negligence or contractual analysis should be used in bilateral contexts, that injurers should be strictly liable when they are unilateral problem solvers, that victims should bear their own losses when only they customarily pay close attention to accident risks and liability rules, and that

actors-through first-party automobile insurance, for example-requires a legal determination that accident deterrence through price-avoidance behavior would be more efficient than the deterrence that problem-solving actors could achieve either through overt risk-avoidance decisionmaking or through price increases and subsequent price-avoidance behavior by other parties. Legal analysts could only make this determination if they could reliably estimate several variables: the extent of the price increases resulting from internalization of losses on "low-attention" activities; the extent to which those price increases would lead to reductions in activity levels and corresponding accident rates; the likelihood that "low-attention" actors would replace the designated activity with relatively safer or more dangerous substitute activities; and the degree to which internalization of losses on problem-solving actors could induce comparable price-avoidance behavior in accident contexts where the problem-solvers do not reduce losses directly through cost-effective preventive measures. These kinds of issues generally would be far more difficult for legal analysts to resolve than it would be for them to identify the presence of at least one category of problem-solving actors and then to internalize losses on those problem solvers.

113. This hierarchical approach is central to my disagreement with Professor Calabresi about the appropriate locus for internalization of automobile accident costs. See infra text accompanying notes 210-22.

114. See infra text accompanying notes $124-25,133-43$ for a description and illustration of this treatment. 
compulsory insurance programs should replace tort litigation in "lowattention" accident settings.

My proposal for strict hability in unilateral problem-solving contexts is similar to Calabresi's recommendation for imposition of strict liability on the category of party that can best conduct the cost-benefit analysis and then act on it. Calabresi premised his analysis on the following arguments: The negligence principle requires courts to examine all possibly relevant circumstances and then to make a difficult, expensive, and frequently unreliable decision about whether specific behavior is "reasonable." It would generally be easier and more consistent for courts to identify the party that can best determine efficient cost-minimization choices tlian for courts themselves to decide what behavior is efficient. $^{115}$ Some entity must be assigued the primary responsibility for making cost-minimization decisions, and Calabresi argued that decentralized actors have better access to relevant information and analytical skills and can generally make more efficient choices than either courts or regulatory agencies. ${ }^{116}$ Strict liability creates more effective deterrence than negligence because it eliminates some of the ambiguity about which party must bear accident losses. ${ }^{117}$ Strict liability would also reduce soine of the transaction costs and injustices associated witl the practical implementation of a negligence system. ${ }^{118}$ In addition to these familiar arguments, I might add that imposition of strict liability on problem solvers who frequently confront a particular type of risk would lead to the development of better information about the cumulative costs of specific kinds of accidents and would therefore enable society to make wiser precautionary investments.

All of Calabresi's arguments would apply equally well to my proposed treatment in circumstances where only one category of actor typically engages in informed problem solving. Calabresi did not, however, demonstrate the utility of his strict liability test in cases where both parties are capable problem solvers or where neither party is likely to make knowledgeable cost-minimization decisions. As suggested above in the discussion of his spectator/player hypothetical, a strict liability test will

115. See Calabresi, supra note 3, at $666-70$; Calabresi \& Hirschoff, supra note 14 , at 1060-61, 1076.

116. See sources cited supra note 111.

117. See Calabresi, supra notc 3, at 658-59, 670-71. Indeed, Calabresi noted that strict liability has occasionally been employed to create a strong risk-avoidance incentive even where the desig. nated party has behaved reasonably and the other party's conduct was unreasonable. See Calabresi \& Hirschoff, supra note 14, at 1065-66. Calabresi does not, however, advocate a strict liablity approach in all accident contexts. See Calabresi, The Problem of Malpractice: Trying to Round Out the Circle, 27 U. TORONTO L.J. 131 (1977); Calabresi supra note 64. I have been unable to ascertain the criteria on which he bases his advocacy of strict liability or an alternative compensation system. See infra note 179.

118. See G. CALABRESI, supra note 1 , at $244-65,274-77$. 
not significantly promote risk-avoidance decisionmaking when neither party is ordinarily an informed problem solver responsive to liability rules. ${ }^{119}$ Calabresi recognized that the category of actors best able to conduct the cost-benefit analysis may not be the category best able to act on the basis of that analysis, ${ }^{120}$ and also that the party best able to achieve short-run accident avoidance may not always be the party that can best prevent accidents in the long run. ${ }^{121}$ His only solution in these cases was for legal analysts to examine the "comparative advantages" of the parties to determine which should be held strictly liable. ${ }^{122}$ In contexts where both categories of actors are effective problem solvers, this "comparative advantages" treatment would frequently entail a consideration of factors as convoluted and difficult to assess as those required under a negligence analysis. ${ }^{123}$

Under Calabresi's strict habihty test, courts or legislatures must first assess the decisionmaking and cost-avoidance abilities of each category of actors before their capacities can be compared. My approach requires a qualitative judgment about problem-solving capabilities, but not a comparative judgment about the respective abilities of the parties. I believe it would generally be easier for legal institutions to decide qualitatively whether typical parties are informed problem solvers in a given accident setting than to evaluate their relative decisionmaking and preventitive capabilities. There would, however, be some cases in which a disparity between the parties' capacities is evident, while it is unclear whether one or both categories should be characterized as "high-attention" actors. The question is which criterion, qualitative decisionmaking ability or relative cost-avoidance ability, is more meaningful im borderline cases. If both parties are incompetent decisionmakers witlı respect to a given risk, why should it be legally sigmificant that one is marginally more capable than the other? If both parties are proficient decisionmakers with respect to a different risk, wliy should legal analysts be required to identify the better one? Calabresi's strategy implies that the relative cost-minimization capacities of the parties are static, but that is untrue for problemsolving actors because their knowledge and abilities may change dynamically in light of applicable legal rules. In bilateral problem-solving contexts, if either category of actors is designated as liable for a particular type of loss, that category presumably will develop tlie information,

119. See supra text accompanying notes 58-63 for iny argument that no liability rule, including strict liability, would significantly affect the risk-avoidance decisions of spectators or ballplayers.

120. See, eg., Calabresi \& Hirschoff, supra note 14, at 1060 n. 19.

121. See G. Calabresi, supra note 1 , at $138-40$.

122. Calabresi \& Hirsclioff, supra note 14, at 1060 n.19; see G. CALABRESI, supra note 1, at 139; Calabresi, supra note 111, at 523 n.8.

123. See Posner, supra note 14, at 213-15; Rizzo, Law Amid Flux: The Economics of Negligence and Strict Liability 9 J. LEGAL STUD. 291, 300-02, 307-09 (1980). 
expertise, and resources necessary to achieve efficient long-run cost reduction. In these bilateral contexts, the courts could seldom make anything approaching an informed determination of which class of actors could eventually become the cheapest cost avoiders in response to changing liability rules and changing circumstances.

Problein-solving actors are generally in the best position to assess the dainages they would suffer if they experience accident losses. ${ }^{124}$ It is also likely that problem-solving victims will insure theinselves against possible accident losses when they know that they must bear those losses. Thus, the question of which is the "best" long-run cost avoider would frequently be indeterminable in bilateral problein-solving contexts, while victims would typically be the most efficient insurers because they can best identify potential losses. This analysis provides the basis for my conclusion that victims in bilateral contexts ordinarily should bear their own losses unless a persuasive reason exists to shift accident costs to the problem-solving injurers. It seems probable that Calabresi did not intend his strict liablity test to supersede risk allocations specified in contracts resulting froin informed bargaiming between the parties. ${ }^{125}$ If that assumption is correct, then both his test and mine would provide for loss shifting in reponse to express warranties, nonadhesive disclaimers, or otlier terms that arise $\mathrm{m}$ an informed contractual setting. Our disagreement in bilateral problem-solving contexts pertains to whether, in the absence of exphicit contractual loss allocations, a negligence test is preferable to a strict liability doctrime that requires legal decisionmakers to identify the "better" long-run cost avoider. These two approaches are coinpared in iny discussion of the Vincent case.

\section{B. Bilateral Problem-Solving Contexts}

The value of any loss allocation strategy inust be measured by its ability to resolve particular conflicts in an efficient and equitable manner. The doctrinal analyses presented below are only suggestive because they do not provide a catalogue of every relevant consideration in each accident context. Instead, they einphasize salient decisionmaking characteristics and attempt to minimize repetition of recurring arguments. Nevertheless, I beheve these analytical sketches demonstrate that my focus on problem-solving behavior or its absence offers a powerful vehi-

124. Expected accident losses are a function of two general variables: magnitude of the risk (probability of injury) and the severity of likely injuries if the risk inaterializes. By definition, both potential victims and injurers must understand accident risks in bilateral problem-solving contexts. Because damages are a function of the victinn's particular characteristics and circumstances, problein-solving victims are generally better able than prospective injurers to estimate the injury losses they inay suffer. See generally Calabresi \& Hirschoff, supra note 14, at 1069 (violinist working in steel mill).

125. See, e.g., Calabresi, supra note 111, at 521 n.6. 
cle for the criticism of many existing tort rules and for the creation of more effective social engineering doctrines.

\section{A Negligence Analysis of Vincent}

In the famous case of Vincent v. Lake Erie Transportation Co. ${ }^{126}$ a vessel repeatedly crashed into a dock during an unusually severe storm. After the cables holding the boat to the dock parted, the captain attached new lines whenever necessary. The court found this behavior was reasonable but nonetheless assigned liability to the boat owner on an intentional tort theory because "those in charge of the vessel deliberately and by their direct effect held her in such a position that the damage to the dock resulted, and . . . thus preserved the ship at the expense of the dock."127 The opinion acknowledged than the dock owner would have to bear the loss if a boat adrift on the lake were driven into the dock by a storn or if the original cables held fast. This means the sole basis for liability was the captain's volitional act in attaching new lines to replace the broken ones. ${ }^{128}$ Professor Epstein attempted to justify the court's holding as follows:

Had the Lake Erie Transportation Company owned both the dock and the ship, there could have been no lawsuit as a result of the incident. The Transportation Company, now the sole party involved, would, when faced with the storm, apply some form of cost-benefit analysis in order to decide whether to sacrifice its ship or its dock to the elements. Regardless of the choice made, it would bear the consequences and would have no recourse against anyone else. There is no reason why the company as a defendant in a lawsuit should be able to shift the loss in question because the dock belonged to someone else. The action in tort in effect enables the injured party to require the defendant to treat the loss he has inflicted on another as though it were his own. If the Transportation Company must bear all the costs in those cases in which it damages its own property, then it should bear those costs when it damages the property of another. ${ }^{129}$

This analysis can be turned on its (empty) head. When botl the dock and boat belong to the dock owner, he would make a comparable cost-benefit analysis and then would accept the lesser loss without legal recourse. If the dock owner must bear the loss when he controls both assets, and when the original cables hold, and when an unmoored ship damages the dock, Epstein provided no explanation whatever for why the dock "company as a [plaintiff] in a lawsuit should be able to shift the

126. 109 Minn. 456, 124 N.W. 221 (1910).

127. Id. at 459,124 N.W. at 222.

128. Id. at $457,124 \mathrm{~N} . \mathrm{W}$. at 221-22.

129. Epstein, $A$ Theory of Strict Liability, 2 J. LeGAL STUd. 151, 158 (1973) (emphasis added). 
loss in question because the [boat] belonged to someone else." 130 The critical issue in this case, mdeed in any tort case, is how losses should be assigned when the instrumentalities are controlled by different parties, and the italicized sentence in the quotation above fundamentally mischaracterizes the problem. It is the dock owner, not the boat owner, who actually suffered the loss, and the dock owner must therefore provide some legal rationale for shifting the loss to the other party.

The obvious argument for loss shifting in this case, and the one the court found dispositive, is that the captain's deliberate decision to replace the cables produced damage to the dock that would not otherwise have occurred. Although he intended to protect the ship, not to harm the dock, the damage was a natural and probable consequence of his actions. Yet the dock owner also made many deliberate choices that contributed to the loss. Had the dock been constructed of steel or stone instead of wood, had it been erected in a different location, had a waterbreak been built, had the boat been assigned a different berth at the dock, had the dock owner provided rubber buffers or some other energy-absorbing protective device, the damage may have been reduced or avoided altogether. These are exactly the types of factors that dock owners usually evaluate in the construction and maintenance of their property, and the risk of damage from an unusually severe storm is among the most obvious risks in operating a dock. There was no intimation in Vincent that the dock owner was unreasonable in any of the choices he made, but neither were the captain's actions unreasonable. ${ }^{131}$

It is true the capptain's actions deflected damage from the boat to the dock, which presents a possible "fairness" argument. Yet, the dock owner profited from offering his dock as a shelter for ships and from buildimg only a reasonably strong structure rather than an impervious one. If the loss is shifted to the boat company, the dock owner retains the benefits derived from his inany "deliberate" choices but escapes the costs associated with the corresponding risks. The unfortuitous parting of the original cables does not inake that result clearly equitable. In my view, neither of these competing "fairness" arguments is more persuasive than the other. ${ }^{132}$

130. This sentence is simply the italicized passage from the Epstein quotation, supra text accompanying note 129, with "plaintif" and "boat" substituted for "defendant" and "dock." Epstein's implicit rationale in support of the court's decision is that the captain "caused" the damage, but this characterization subsumes the central issue-should the loss be attributed to the captain's actions, the dock owner's choices, or the storm itself?

131. For the observation that the plaintiff's behavior was not contributorily negligent, see Rizzo supra note 123 at 297. Like Epstein, whose analysis he followed, Professor Rizzo provided no legal explanation for why reasonable behavior by the dock owner should be treated differently from reasonable behavior by the boat owner. See id. at 296-97.

132. Another possible fairness argument is that the captain "used" the plaintiff's property for his own benefit and therefore should be required to provide compensation for resulting damages. 
The essential point is that both boat operators and dock operators will generally be informed problem solvers with respect to this type of risk. Contrary to Calabresi's strict liablity analysis, there is no reason why courts should be required to, or can, determine which of these categories of actors is likely to be the cheapest cost avoider. Docks can provide protective buffers, but so can ships. Dock owners are generally in a better position to decide low strong docks should be for their particular locations and expected usage, but boat masters can better decide which docks to use and, perhaps, which bertlis are safer in varying weatler conditions. Dock owners can better assess the probable damage to their property if boats are sheltered during storns, but boat owners can better assess probable damage to their vessels if they leave the dock. Boat owners control the lines attaclied to their boats and dock owners control the lines attached to their docks, which means the parties are equally able to avoid inefficient losses. ${ }^{133}$ It is unclear which party is the better riskavoidance decisionmaker, but eacl problem-solving actor is usually in the best position to insure his own property agamst potential losses. Docks shelter many different kinds of vessels. Boats visit many different kinds of docks. Each owner knows the value of his property and would be relatively knowledgeable about its vulnerabilities, but could only speculate about the likely damages to the assets of others. Thus, the liability system matrix indicates that dock owners should prevent or insure against dock losses and boat owners should do the same for boat losses.

This allocational doctrine probably slould not be extended to cases in which problem-solving actors make inefficient risk-avoidance decisions. Bilateral problem-solving contexts are those in which both parties are responsive to the potential costs of legal liability and botli are capable of informed choices. Calabresi's treatment would designate one category of actors as strictly liable only at the cost of clearly imdicating that the other problem-solving category is not liable for specific accident losses. ${ }^{134}$

The court evidently found this argument persuasive because it drew anologies to circumstances in which a starving man is given sustenance or someone appropriates a cable that does not belong to him. In both of those contexts, the court indicated that compensation is required. See 109 Minn. at 460,124 N.W. at 222. However, unlike in those hypotheticals, the captain in Vincent was arguably restoring the status quo that existed before the emergency arose. The boat was moored to the dock when the storm became foreseeable, and it was still moored to the dock im the same position after the captain's deliberate actions.

133. With respect to short-run cost minimization, the cooperation of both parties is required for the boat to remain at the dock during a storm, and either party is able to detach the limes when it is more efficient for the boat to leave.

134. This assumes that actors can identify in advance which category will be designated by legislatures or courts as best able to conduct the cost-benefit analysis and then act on it with respect to particular types of accident losses. If parties cannot anticipate which class of actors will be assigned strict liability, then few of the social engineering advantages Calabresi claimed for strict liability would materialize. See, e.g., supra, text accompanying notes 115-17. If legal attempts were made to implement Calabresi's strict liability test in real conflicts, I doubt the required determina- 
Cost-conscious problem solvers are especially prone to engage in risky behavior when they recognize that some other party will be liable for any losses that result from their activities. ${ }^{135}$ The failure to internalize negligent accident losses in bilateral contexts would dilute the incentives for actors to avoid choices that further their private interests but are socially inefficient. If, for example, a Calabresian strict liability test leads to the conclusion that dock owners are the "better" cost avoiders for dock losses, boat owners will have little incentive to remove their vessels even when the probable damage to the dock exceeds the probable dainage to the boat if it leaves its berth. Conversely, if the boat owner must bear his own losses even when the dock owner's behavior is unreasonable, then dock operators will have little incentive to allow ships to remain at their berths during storms. Absent tort liability for inefficient choices, neither problem-solving actor will have sufficient motivation to protect his own or the other party's property from damage.

Bilateral problem-solving contexts are quite rare because they require both categories of actors to meet all of the criteria for effective cost-mimimization decisionmaking. ${ }^{136}$ In these selective circumstances, legal doctrines must ensure that the creation of risk-avoidance incentives for one type of party does not dilute equally important deterrent incentives for other problem-solving parties. Because both categories of actors in Vincent are capable decisionmakers who will minimize losses if the proper incentives are created, this is not a case where "faultless" parties should be held hable in order to encourage that class of actors to protect others against their own lack of care. ${ }^{137}$

From the perspectives of deterrence and transaction costs, ${ }^{138}$ the primary disadvantage of a negligence standard in bilateral accident contexts is that it operates on the basis of the parties' behavior in each case rather than on a category-wide level. ${ }^{139}$ In comparison with victim liabil-

tions would be either clear or foreseeable by affected categories of actors in many cases. See infra text accompanying notes 141-43, 178-80, 276-77.

135. See supra text accompanying notes $94-95$.

136. See supra text accompanying note 99.

137. For illustrations of accident contexts in which problem-solving actors should be required to protect "low-attention" actors against their own foreseeable lack of care, see infra text accompanying notes 194-98, 223-35.

138. The delays and litigation expenses associated with a negligence system, although a signifcant consideration, are less likely to warp the eventual outcome in bilateral problem-solving contexts than in automobile accident, medical malpracticc, or other contexts where at least one type of party is a "low-attention" category. Bilateral settings typically feature organizations or commercial cnterprises that have adequate access to information, relevant expertise, and litigation resources.

139. See G. CALABRESI, supra note 1, at 244-59; Calabresi \& Hirschoff, supra note 14, at 1067 70. Although the transaction costs of a case-by-case negligence approach are frequently substantial, the transaction costs associated with Calabresi's strict liability test could also be high in bilateral problem-solving accident contexts. These are the settings in which it would usually be difficult for legal analysts to identify the better cost-benefit decisionmakers and cheapest cost avoider because 
ity or any arbitrary strict liability rule, a negligence treatment may provide less notice to categories of actors about prospective loss allocations. The uncertainty derived from a negligence treatment ${ }^{140}$ would, however, be a serious drawback of my approach only if it were true that problemsolving actors are more likely under a strict liability rule to draft contract terms that allocate the consequences of eacli other's inefficient behavior. ${ }^{141}$ The great problem with strict liability in bilateral problen-solving settings is that it allows, and may encourage, nondesignated actors to engage in inefficient beliavior. This disadvantage could be reinedied if the parties specifically allocate unreasonable losses through contract terms, but any attempt to anticipate and assign inefficient accident costs may induce a breakdown in contractual negotiations. Contracts between businessmen or between otlier informed actors seldom enumerate the allocational consequences of unreasonable, "bad faith," or intentionally harmful conduct because the process of identifymg those possibilities would greatly increase transaction costs and would frequently undermine the climate of trust and cooperation necessary for most consensual agreements. The contract between the dock owner and boat owner in Vincent, for example, did not cover the circumstances that actually occurred. ${ }^{142}$

problem-solving injurers and victims may both have available a wide range of short-run and long-run risk-avoidance strategies. Moreover, Calabresi's approach would often replace case-by-case negligence litigation with case-by-case contract construction in circumstances where the losses associated with inefficient behavior must be allocated. See infra text accompanying notes 141-43, 163 .

140. This uncertainty could reduce the propensity of parties to determime loss allocations themselves through contractual arrangements. Uncertainty arising from negligence consequently may increase the number of cases in which courts, rather than problem-solving actors, must identify the appropriate locus for internalization of accident costs.

141. In terms of prospective certainty, a rule of strict victim hability or any arbitrary, but clear, strict liability rule would be more efficient at promoting contractual loss allocations by the parties than would Calabresi's strict hability test. In reality, parties would often be uncertain and would disagree about which category of actors is the best cost-benefit decisionmakers and cheapest cost avoiders, and about how courts would resolve particular disputes on the basis of the parties' "comparative advantages" when one is the better decisionmaker and the other is the cheaper cost avoider; see supra text accompanying notes 120-25; or when one party is the better insurer and the other is a better risk avoider. With respect to Vincent, Calabresi observed: "[T]he dock owners could probably estimate with relative ease the damage a given boat would inflict to a dock during a violent storm, while shipowners might find it difficult to say which dock would most likely be hit by a violent storm." G. CALABRES1, supra note 1, at 169 n.28. This implies that dock owners may be better decisionmakers about dock losses. Yet, the actual dock owner in Vincent claimed that several of the boat captain's choices were inefficient. See 109 Minn. at 458, 124 N.W, at 221. Had Calabresi's strict liability test been in effect, the dock owner would surely have argued that the captain was the better risk-avoidance decisionmaker and cheaper cost avoider. Although there would be some circuunstances where one class of actors may be the most proficient decisionmakers even when the other category of actors is negligent, there would undoubtedly be many circuinstances where a category of actors is best able to avoid losses arising from its own inefficient behavior but not from their efficient behavior. I believe Calabresi's strict liability test provides no inore certainty than a negligence treatment in these circumstances. It also appears likely that any attempt to apply his test would frequently require case-by-case adjudication under either a tort or contract theory.

142. In Calabresi's brief discussion of Vincent, he noted (like Professor Coase) that any liability 
Similarly, the express risk-allocation clause in the Polemis case did not apply to losses resulting from negligent behavior. ${ }^{143}$ Unless contracts in bilateral settings explicitly allocate losses from different kinds of unreasonable actions, the courts will have to interpret whatever contractual terms do exist on a case-by-case basis to determine how inefficient losses should be allocated. They then must also decide, again on a particularized basis, whether specific losses stem from reasonable or inefficient behavior. Thus, it appears uulikely that the additional legal certainty provided by any strict liability treatment would significantly reduce litigation costs or promote contractual allocation of unreasonable accident losses.

\section{Product Warranties Versus Strict Liability}

In Greenman v. Yuba Power Products, Inc. ${ }^{144}$ Justice Traynor persuaded the California Supreme Court to accept a strict liability analysis in a situation where a defective power tool caused physical injuries to a consumer. In contrast, Justice Traynor refused, in Seely v. White Motor Co. ${ }^{145}$ to apply strict product liability for econornic losses arising in a "coinmercial" setting. The plaintiff in Seely was the purchaser of a truck that had persistent mechanical probleins over a one-year period. The owner refused to inake further payments and successfully sued for lost business profits and a refund of his prior payments. The court held the manufacturer responsible for econoinic losses "only because it warranted the truck to be 'free from defects in material and workmanship under normal use and service." "146 Justice Traynor noted that "[t]lye law of sales has been carefully articulated to govern the economic relations between suppliers and consumers of goods," 147 and further that a buyer can "be fairly charged with the risk that the product will not matcli his economic expectations unless the manufacturer agrees that it will."148 Justice Traynor thought that limiting the manufacturer's ability to issue warranty disclaimers would undesirably require "the consuning public

rule would, in theory, lead to an efficient level of losses because the parties would adjust activity prices and other contractual terms to take potential accident costs into account. See G. CALABresI, supra note 1, at 162. Yet the actual contract between the boat owner and dock owner did not allocate the type of loss that occurred. My point is that no liability rule-neither negligence nor Calabresi's strict liability test-is likely to inducc actors to allocate losses resulting from aberrational circumstances or inefficient behavior through explicit contract terms. If the parties do not do so, the courts would frequently be required to undertake a case-by-case "contract" analysis that would not be significantly less expensive or intrusive than the negligence analysis I propose in bilateral problem-solving contexts.

143. See In re Polemis and Furness, Withy \& Co., 3 K.B. 560, 572, 573, 576 (1921).

144. 59 Cal. 2d 57, 377 P.2d 897, 27 Cal. Rptr. 697 (1963).

145. 63 Cal. 2d 9, 403 P.2d 145, 45 Cal. Rptr. 17 (1965).

146. Id. at 16, 403 P.2d at 150, 45 Cal. Rptr. at 22.

147. Id. at 15, 403 P.2d at 149,45 Cal. Rptr. at 21 .

148. Id. at 18, 403 P.2d at 151, 45 Cal. Rptr. at 23. 
to pay more for their products so that a manufacturer can insure against the possibility that some of his products will not meet the business needs of some of his customers." 149 He also asserted that there was no "inequality in bargaining position" in this case because the plamtiff, "whose business is trucking, could have shopped around until he found the truck that would fulfill his business needs." 150

In a trenchant argument for the application of strict liability in Seely, Justice Peters observed that the court's distinction between physical and economic losses was arbitrary. A plaintiff could, for example, recover lost business income if it resulted from his sustaining a broken leg through product use, but not if the same economic loss arose directly from the inadequate performance of a product. ${ }^{151}$ Justice Peters then continued:

The majority recognize that the rules governing warranties were developed to meet the needs of "commercial transactions." If this is so, then why not look to the transaction between the buyer and the seller and see if it was a "commercial" transaction rather than a sale to an ordinary consumer at the end of the marketing chain? How can the nature of the damages which occur later, long after the transaction has been completed, control the characterization of the transaction? Any hine which determines whether damages should be covered by warranty law or the strict liability doctrine should be drawn at the time the sale is made. ${ }^{152}$

Justice Peters acknowledged that a "line must be drawn somewhere" between strict hability and the "disclaimer and notice provisions of the Commercial Code."153 He then attempted to create this line by distinguishing between commercial transactions and purchases made by an "ordinary consumer." 154 Justice Peters argued in Seely that the plaintiff, the owner-driver of a single truck, should be regarded as an ordinary consuiner at the end of the marketing chain, unlike the operator of a fleet of trucks who can be expected to possess considerable expertise and bargaining power. ${ }^{155}$

The presence or absence of informed problem-solving ability provides a more useful basis for selection of a liability strategy than either Justice Traynor's distinction between economic losses and physical injuries or Justice Peters' distinction between commercial transactions and consuiner purchases at the end of the marketing chain. When a manu-

149. Id. at 19,403 P.2d at 151,45 Cal. Rptr. at 23.

150. Id. at 19, 403 P.2d at 151-52, 45 Cal. Rptr. at 24 .

151. See id. at 22, 403 P.2d at 153-54, 45 Cal. Rptr: at 25-26 (Peters, J., concurring and dissenting).

152. Id. at 26, 403 P.2d at 156, 45 Cal. Rptr. at 28.

153. Id. at 28, 403 P.2d at 158,45 Cal. Rptr. at 30.

154. See id. at 28, 403 P.2d at 157-58, 45 Cal. Rptr. at 29-30.

155. See id. 
facturer sells cosmetic supplies to a beautician, for example, the buyer can reasonably be expected to understand some kinds of product risks but not others. Beauticians may know how to avoid injuries resulting from improper apphication of cosmetics, but they are usually in no better position than the ultimate consumer to identify long-term toxic hazards associated with product use. In the latter context, liability will induce manufacturers but not beauticians to become proficient at chemical analysis, biological testing, acquisition of epidemiological data from longitudinal studies, and other practices necessary to determine toxic risks. Thus, a warranty analysis may be appropriate for allocation between manufacturers and beauticians of losses resulting from product misuses but not from latent toxic risks. Because beauticians are not effective problem solvers for toxic hazards, it should be immaterial that they are neither the ultimate product consumers nor at the end of the marketing cham. Furthermore this loss allocation strategy should not depend on whether there are many competing cosmetics available, and hence no apparent inequality of bargaining power, because free choice will not promote efficient cost-minimization decisions when typical purchasers are incapable of making knowledgeable choices.

The decisionmaking characteristics of the parties with regard to specific types of risks, rather than a purchaser's position in the marketing cham or the "commercial" nature of the transaction, is the important consideration from a social engineering perspective. In Randy Knitwear, Inc. v. American Cyanamid Co. ${ }^{156}$ for example, a producer of sportswear was able to recover damages when a shrinkproofing chemical did not perform as expected, despite the alleged existence of an express warranty disclaimer and the absence of privity. ${ }^{157}$ The court stressed the purchaser's reliance on explicit representations made by American Cyanamid, but in one passage the opinion described the basis for the holding as an application of strict liability. ${ }^{158}$ Notwithstanding the commercial character of this transaction, thousands of clothing producers cannot be expected to develop the specialized expertise necessary to test the effectiveness of each batch of resins purchased from chemical inanufacturers. Clothing producers are also unlikely to acquire enough expertise with a particular chemical to develop an actuarial history describing the incidence of performance failures. Although clothing producers probably could msure against this type of loss, internalization of losses on the

156. 11 N.Y.2d 5, 181 N.E.2d 399, 226 N.Y.S.2d 363 (1962).

157. There was an express warranty disclaimer in the contract between the plaintiff and the fabric vendors. Thus, the "privity" issue was whether the plaintiff could recover directly from the manufacturer of the shrinkproofing chemicals despite the absence of any remedy against the vendors from whom the plaintiff bought the fabric. See id. at 9 \& n.1, 14, 181 N.E.2d at 400.01 \& n.1, 403, 226 N.Y.S.2d at $365 \&$ n.1, 369.

158. Id. at 15,181 N.E. $2 \mathrm{~d}$ at $403-04,226$ N.Y.S. $2 \mathrm{~d}$ at $369-70$. 
chemical manufacturers would be preferable because only they are in a realistic position to prevent these losses. Thus, regardless of whether the label "strict liability" or "implied warranties of fitness and merchantability" is adopted, manufacturers of shrinkage-control chemicals should not be allowed to avoid hability through warranty disclaimers because purchasers typically are not effective problem solvers for this kind of product-related loss.

On the other hand, there are some categories of product-related risks where "ordinary consumers" do function as reasonably effective decisionmakers. ${ }^{159}$ To cite one common illustration, typical people do not require specialized expertise, actuarial histories, or sophisticated cost-accounting procedures to assess the risks of using a knife as a toothpick. The important consideration here is not the legal fiction that this type of product misuse is "unforeseeable" from the knife manufacturer's viewpoint, but rather that consumers can evaluate this risk in a reasonable informed manner. Thus, under the proposed liability system matrix, the knife manufacturer would not be liable for this type of risk unless his product design is unreasonable. ${ }^{160}$ Phrases such as "ordinary consumer," "commercial transaction," and "at the end of the marketing chain" should not be accorded tahismanic significance; they are useful only to the extent that they provide insight into the decisionmaking characteristics and probable behavior of typical actors confronting diverse product risks.

\section{Unilateral Problem-Solving Contexts}

In accident contexts where one category of actors is likely to engage in informed problem-solving behavior and the other categories are not,

159. See G. CALABRESI, supra note 1, at 163-64; Priest, supra note 96, at 1308-13. I intend in a future essay on strict product liability and consumer warranties to criticize Professor Priest's assumption that consumers are generally effective problem solvers with respect to product reliability and product-related safety liazards. Nevertlieless, there are some specific product risks that typical consumers can evaluate in a reasonably informed manner. For a skeptical view of Priest's assuunption that contractual terms betwecn producers and consumers are generally efficient, sec Note, Efficiency and a Rule of "Free Contract": A Critique of Two Models of Law and Economics, 97 HARV. L. REV. 978, 980-88 (1984).

160. In bilateral problem-solving contexts, where both parties are effective cost-benefit decisionmakers with respect to a given risk, the liability system matrix indicates that victims slould bear their own losses unless the injurer is negligent or there is an explicit contractual provision that governs loss allocations between the parties. The current "design defect" strict product liability doctrinc adopts a negligence approach, except that foreseeability of injuries is generally imputed to the manufacturer. Altlougl $I$ intend in a future essay to question tle wisdom of a judicial riskutility balancing approacl in most product-related aceident contexts (where manufacturers should be characterized as informed problem solvers and typical consumers as "low-attention" actors), a negligence treatment may be appropriate in product contexts where average users are knowledgeable about, and likely to pay attention to, specific risks. The critical issue is not whetler consumers "could be" the cheapest cost avoiders, see R. POSNER, supra note 3, at 81-83, but whetlier typical consumers are in reality competent and willing to evaluate particular product risks. 
strict liability should be imposed on the problem-solving actors. Many current tort doctrines misallocate losses in unilateral problem-solving risk contexts, especially where a particular party "could be" the cheapest cost avoider but, in reality, will seldom achieve effective risk-avoidance decisionmaking. Strict liability in unilateral problem-solving risk contexts creates the maximum incentive for capable and attentive decisionmakers to select efficient cost-minimizing choices, and also encourages problem-solving injurers to protect victims against losses resulting from their own foreseeable careless behavior.

\section{Liability of Common Carriers}

Typical common carriers are problem-solving actors with respect to transportation-related risks while typical passengers and shippers are not. Indeed, carriers encourage their customers to rely on them for safe transportation. Most carriers are large enterprises that can acquire actuarial data on specific accident causes, inaintain detailed cost-accounting systems, and adapt their risk-avoidance behavior in response to costs imposed by liability rules. Carriers routinely train their employees to minimize recognized risks, and they employ specialists in accident avoidance to identify those risks and to develop cost-effective preventive measures. Because common carriers are better able to decide whether it would be more efficient to make additional investınents in precaution or to carry additional insurance, internalization of accident costs on carriers through tort liability is more appropriate than internalization on custoiners through risk-related insurance. ${ }^{161}$ Internalization on carriers would also create desirable coinpetitive advantages for safer carriers and for safer modes of transportation. ${ }^{162}$ In short, virtually all of the problemsolving characteristics identified in this Article cut in favor of imposing strict liability on common carriers.

161. Carriers undoubtedly will insure against risks they determine are not worth avoiding. Although their customers "could" insure through some haphazard combination of insurance programs, the transaction costs of customer insurance are likely to be higher than of carrier insurance. Customers may spread losses through general hfe and health insurance, credit card trip insurance, and vending machine trip insurance policies. Common carrier insurance, however, entails a much smaller number of discrete transactions than would customer insurance, and common carriers are far more hikely to know the magnitude of transportation-related risks than are their passengers. This context illustrates the general principle that the transaction costs of insuring against a given type of accident may vary widely for different categories of actors. See G. CALABRES1, supra note 1, at 164; R. POSNER, supra note 3, at 74-79.

162. Internalization of losses on airlines, for example, would create a competitive advantage for safer carriers if accident rates differ significantly and if insurance premiums are tailored to the accident histories of particular airlines. Internalization has the same competitive effects among substitute activities, such as airlines, railroads, and interstate bus lines. Under a negligence analysis, courts in theory ought to consider the accident rates and prevention costs associated with product substitutes as well as with competitive products within the same market, but they seldom if ever can do so in practice. 
When the negligence system was in the ascendency, the courts used reliance and deterrence arguments to justify requiring common carriers to exercise "the highest degree of vigilance, care, and precaution."163 Courts also employ res ipsa loquitur or burden-shifting procedures to facilitate recovery by accident victims in cases where carrier negligence is unclear. ${ }^{164}$ Taken together, these doctrines come close to imposing strict liability on common carriers. The question is whether there is any useful purpose to be served by allocating accident costs to victims in the occasional case where losses occur despite the carrier's "highest degree" of care. A shift to strict liability would not create a significant marginal deterrent incentive precisely because the traditional duty imposed on carriers is very stringent. Allocation of all losses to carriers would, however, ensure that loss spreading through insurance reduces "dislocation costs" associated with victiln injuries. ${ }^{165}$ Strict liability would create competitive advantages for modes of transportation that are less vulnerable to "acts of God" or other nonneghigent accident causes. Strict liability would reduce litigation costs and uncertainties by obviating the need for courts to determine whether accidents should be attributed to conditions the carrier should have anticipated and guarded against, or to circumstances outside the carrier's control. Strict hability would also eliminate the requirement for plaintiffs to identify the cause of the accident and possible deficiencies in the defendant's behavior. This is an important consideration because victims ordinarily have inuch less access to relevant information and expertise than do carriers. The only argument for allocating transportation-related losses to passengers is that common carriers are not "at fault" in soine accidents, but neither are the victims "at fault" in these cases.

In Goldberg v. Kollsman Instrument Corp.,${ }^{166}$ for example, the victim died in an accident caused by the failure of an airplane altimeter. Because the instrument conformed to federal safety standards and must have been tested many times, it is unlikely that the defendants could have discovered the latent defect before the altimeter malfunctioned. Under traditional common carrier doctrine, the airline would not be liable unless the plaintiff could not prove the carrier was negligent in its main-

163. Orr v. New Orleans Pub. Serv., Inc., 349 So.2d 417, 419 (La. App. 1977); see also Pennsylvania Co. v. Roy, 102 U.S. 451, 456 (1880); Carson v. Boston Elevated Ry. Co., 309 Mass. 32, 35, 33 N.E.2d 701, 703 (1941).

164. See Prosser \& KeEtoN, supra note 48, at 252.

165. Although all passengers "could" insure, there is no reason to believe that all will do so or that they would choose an efficient level of insurance in the absence of knowledge about various transportation-related risks. Busses, for example, are frequently patronized by children and poor people who are characteristically underinsured.

166. 12 N.Y.2d 432, 191 N.E.2d 81, 240 N.Y.S.2d 592 (1963). 
tenance or operation of the plane. ${ }^{167}$ The plaintiff in Goldberg was, however, allowed to recover from the aircraft manufacturer on a strict product hability theory. ${ }^{168}$ In dissent, Judge Burke argued that it would be irrational for courts to hold the manufacturers to a higher standard of care than the common carriers. ${ }^{169}$

If consistency were achieved by imposing strict liability on carriers for all accident losses, the plaintiff would not have to identify the precise cause of the accident, and the court often would not be required to allocate the loss among several problem-solving defendants. The airline, the aircraft vendor, and the subcontractor who produced the altimeter would all be familiar with the instrument's specifications and performance record, and they would generally possess sufficient knowledge and bargaining power to assign this type of risk among themselves through contractual arrangements. A court may have to determine the accident's cause $\mathrm{m}$ an action for contract damages if the problem-solving parties do not reach agreement, ${ }^{170}$ but there is no reason why a judge rather than the problem-solving parties should define the proper locus for loss internahzation. Any of these problem-solving actors will generally be a better loss spreader than accident victims would be, and internalization of accident costs on any of the problein-solvers will produce more efficient riskavoidance decisions than would internalization of losses on the random passengers mvolved in airplane crashes. Application of the proposed liability system matrix would enable victims to recover from common carriers on a strict hability rule, and yet would allow allocation of losses among the problem-solving defendants under a contractual analysis. ${ }^{171}$

167. See id. at 437-38, 191 N.E.2d at 83-84, 240 N.Y.S.2d at 596-97 (Burke, J., dissenting). See generally supra text accompanying notes 163-64.

168. See id. at 437,191 N.E.2d at $82-83,240$ N.Y.S.2d at 595. The court did not explain why the common carrier should escape liability for an unavoidable accident while the manufacturer should be liable despite its inability to prevent the loss.

169. See id. at 438-39, 191 N.E.2d at $84-86,240$ N.Y.S.2d at 596-97 (Burke, J., dissenting). Judge Burke thought the common carrier would not be liable if it had manufactured the plane and a "reasonable" construction defect then caused the accident, and he therefore questioned why a diffrent liability doctrine should apply when the airline purchases a plane that it could have made itself.

170. This is the same point made above in my discussion of the Vincent case. See supra text accompanying notes 138-43. If the contracts between the common carrier, aircraft vendor, and subassembler assign "unreasonable" and "reasonable" losses to different parties, then the courts may be required on a case-by-case basis to determine whether specific accident costs stem from efficient or inefficient behavior by each actor. If the contracts do not explicitly allocate "unreasonable" losses, then the party faced with liability is likely to argne that the contract implicitly assigned accident costs to the ineficient actor (assuming their identities differ), and a court would have to construe the contract on a particularized basis to determine where inefficient losses should be assigned. The court then must also deeide whether given losses resulted from incfficient behavior.

171. If there were no contractual loss allocation among problem-solving defendants, I would regard an action for contribution or apportionment under the liablity system inatrix as if it werc an original negligence action. Thus, losses would remain on whichever problem-solving defendant was sued by the plaintiff unless this defendant could show that the behavior of another problem-solving 


\section{The "Rule" in Rylands v. Fletcher}

Rylands v. Fletcher ${ }^{172}$ held a reservoir owner strictly liable when impounded water flooded an adjacent mine. American courts have construed the decision to stand for three propositions: strict liability applies when something "likely to do mischief" escapes from the defendant's land and damages the property of another; ${ }^{173}$ when a "non-natural" use of land creates harm, where "non-natural" means a divergence from an undeveloped or agrarian state of nature; ${ }^{174}$ or when a "non-natural" use results in damage, where "non-natural" means out of the ordinary in comparison with customary uses of property in a particular place and time. The "likely to do mischief" rule was justified on a deterrence rationale and has gradually been limited to "ultrahazardous" or "abnormally dangerous" activities. ${ }^{175}$ American courts that interpreted Rylands to require strict hability whenever the state of nature is altered have uniformly rejected this doctrine on the grounds that development is desirable in an expanding civilization. ${ }^{176}$ Most jurisdictions have, however, accepted the "non-natural" strict liability rule when apphed to activities that are unusual or abnormal for a given location. ${ }^{177}$

The "non-natural" strict liability rule is generally compatible with my Article's emphasis on the decisionmaking characteristics of typical actors in specific accident contexts. It would be unrealistic to expect other property owners in the surrounding area to protect themselves against the hazards associated with unusual activities, but these owners are likely to be more familar with the risks posed by normal uses of land in the region. The particular activities that should be regarded as "natural" will vary with local practices and circumstances. Because only the "non-natural" user will typically be an informed problem solver with respect to the risks created by his activities, the law should impose a strong incentive for him to mimmize possible accident losses even when his "non-natural" use is reasonable in the sense that it increases net social utility. Strict liability for losses resulting from "non-natural" uses would encourage the problem-solving actor to protect or insure potential victims in contexts where they ordinarily will not protect themselves.

actor was inefficient. I would not allow a problem-solviug defendant to obtain contribution or apportionment of damages from a "low-attention" defendant.

172. 3 L.R.-E. \& I. App. 330 (H.L. 1868), aff'g 1 L.R.-Ex. 265 (1866), rev'g 159 Eng. Rep. 737 (Ex. 1865).

173. This treatment derives from Justice Blackburn's opimion in the Exchequer Chamber. See Fletcher v. Rylands, 1 L.R.-Ex. 265, 279-80 (1866).

174. The "non-natural" use language derives from Lord Cairns' opinion. See Rylands v. Fletcher, 3 L.R.-E. \& I. App. 330, 338 (H.L. 1868).

175. See Prosser \& KEETON, supra note 48 , at 545-59.

176. See, e.g., Brown v. Colhus, 53 N.H. 442 (1873); see also Prosser \& KeEton, supra note 48, at 549-51.

177. See Prosser \& KeEton, supra note 48, at 549-51. 
In a similar effort to pour "old wine into new bottles," Calabresi suggested that the "non-natural use" rule may be consistent with imposition of strict hability on the category of actors that could best conduct the cost-benefit analysis and then act on it. ${ }^{178}$ When one actor is an effective problem solver and the other is not, Calabresi's approach and mine would usually lead to the same strict hability allocation. My analysis, however, largely dispenses with the need to differentiate between decisionmaking and cost-avoidance capabihties. People who do not pay attention to specific risks and corresponding legal rules in an informed manner are unlikely to make effective cost-minimization choices even when they "could be" the cheapest cost avoiders. The Rylands doctrine illustrates the conceptual weakness in the second part of Calabresi's test, which I regard as a quixotic attempt to achieve ideal efficiency in all cases. ${ }^{179}$ The "non-natural" user will typically be the better decisionmaker, but there is no reason to assume he would generally be the cheaper cost avoider. It is unclear, for example, that reservoir owners are better able than mine owners to prevent incursions of water into inine shafts. ${ }^{180}$ The rationale for miposing strict hability on "non-natural"

178. See Calabresi \& Hirschoff, supra note 14, at 1065 \& n.36. This brief reference was part of Calabresi's general discussion of "assumption of risk" as a form of victim strict liability.

179. Although Calabresi occasionally cites the need for realism in the choiee between competing hability systems, see Calabresi \& Hirschoff, supra note 14, at 1059, his inode of analysis would require legislatures or courts to inake many difficult coinparative judgments-including assessments of relative decisionmaking and cost-avoidance capabilities, long-run versus short-run avoidance abilities, primary accident cost avoidance versus insurancc, negotiation, and other transaetion costs, broader versus narrower subcategorizations of types of activities, alternative allocations of different kinds of damages, and social engineering effects versus distributional consequences. All of these considerations would be relevant to an optimal allocation of accident losses, but I doubt the practical capability of legal decisionmakers to examine them all in a cost-effective and timely manner. Despite the brilliance of his conceptualizations, Calabresi seldom addresses realistic implementation constraints and seldom provides concrete illustrations where all relevant considerations are balanced. In one essay, for example, he observed that optimal deterrence soinetimes requires both injurers and victims to modify their behavior. Then he continued:

It is perfectly possible to determine that in certain categories of accidents the cost-benefit decision can best be made, and acted upon, if part of the costs are borne by the injurer and part by the victim. Strict hability, as I have defined it, is in no way limited by any requirement that all the loss inust lie on one class or the other. Nor are strict liability decisions limited to dividing the loss, where division is appropriate, in a purely quantitative way. Rather, one may hold that the desirability of avoiding the risk of certain types of damages is best determined and acted on by victim classes, even though the injurer can best make and act upon the necessary cost-benefit analysis for the accident itself and the basic damages that flowed from it.

Calabresi, supra note 3, at 669 (emphasis in original). Surely, it would be difficult for legal decisionmakers to achieve this degree of sophistication in their analyses, especially when relative decisionmaking and cost-avoidancc advantages of the parties differ. See supra text accompanying notes 119-23. For other examples of ambiguous analyses, see Calabresi, supra note 111, at 523 n.8 (riskavoidance versus negotiation costs); Calabresi, supra note 108, at 99-100 (foreseeability of types of damages). My approach, in contrast, places primary emphasis on the decisionınaking characteristics of categories of actors. I am prepared to accept a ineasure of theoretical inefficiency in return for a simpler and more administrable loss allocation test.

180. Lord Cranworth pointed out in Rylands v. Fletcher, 3 L.R.-E. \& I. App. 330, 341 (H.L. 
users is that other property owners ordinarily cannot assess the risks of "non-natural" activities and therefore will not protect themselves regardless of whether they could minimize accident costs efficiently. Actual decisionmaking ability and propensity, not some hypothetical capacity for efficient cost avoidance, should be the decisive criterion in loss allocation doctrines.

Under the Rylands doctrine, a negligence test is adopted for activities that are customary or "natural" in a region. The problem with this treatment is that, while potential victims usually are ineffective decisionmakers for "non-natural" risks, the opposite generalization is unwarranted for "natural" risks.. In a location with a high concentration of manufacturing industries, for example, pollution inay be a commonplace activity, but typical property owners and residents im the area will seldom be informed problem-solvers with respect to pollution hazards. In Turner v. Big Lake Oil Co. ${ }^{181}$ the Texas Supreme Court refused to apply strict liability to the impoundment of water because in an arid region "the storage of water is a natural or necessary and common use of the land." 182 Yet the propensity of oil companies in Texas to store large quantities of water does not assure that surrounding property owners would usually be able to inake efficient loss-avoidance or insurance decisions about water storage risks. The normalcy of an activity for the place and time is one relevant factor, but should not be regarded as the sole or decisive criterion in the legal decision whether affected actors are hikely to be informed problem solvers for specified accident risks.

\section{Spectator Injuries in Sports Arenas}

The inposition of hability for accidental injuries at sports events on either spectators or ballplayers will seldoin promote efficient behavior modification, but the social engineering effects of allocating losses to arena operators should also be considered. In Davidoff ex. rel. Davidoff v. Metropolitan Baseball Club, Inc., ${ }^{183}$ a fourteen-year-old girl was severely injured when struck by a foul ball at Shea Stadium while "her attention was diverted from the game."184 She had been sitting in "a box seat behind first base, separated from the playing field by only a three-

1868), that miners inust bear their own losses when water naturally flows into their property, even if it does so through an upper mine shaft belonging to another property owner. Once a miner must install pumps or otherwise protect against damage from natural flows of water, the marginal costs of his protecting against unanticipated flows from nearby reservoirs may be lower than the prevention costs for reservoir owners.

181. 128 Tex. 155, 96 S.W.2d 221 (1936).

182. Id. at 165,96 S.W.2d at 226.

183. 61 N.Y.2d 996, 463 N.E.2d 1219, 475 N.Y.S.2d 367 (1984).

184. Id. at 997,463 N.E.2d at 1220,475 N.Y.S.2d at 368 . 
foot fence,"185 and her attorney offered to prove that "she was given an assigned seat in an unscreened area in which there had been prior spectator injuries." ${ }^{186}$ The New York Court of Appeals, relying on a recent opinion that involved a sandlot baseball field, dismissed the plaintiff's complaint without allowing her to establish that her seat presented an unreasonable risk of injury:

"[W]here a proprietor of a ball park furnished screening for the area of the field behind home plate where the danger of being struck by a ball is greatest and that screening is of sufficient extent to provide adequate protection for as many spectators as may reasonably be expected to desire such seating in the course of an ordinary game, the proprietor fulfills the duty of care imposed by law and, therefore, cannot be liable in negligence." Here, there has been no showing by plaintiff that (1) defendants failed to erect a screen behind home plate providing adequate protection in that area, and (2) there are not sufficient seats behind the screen to accommodate as many spectators as reasonably may be expected to desire such seating. No evidence that the screen was inadequate was presented, and it is undisputed that there were unoccupied seats behind the screen at Shea on the day plaintiff was injured. ${ }^{187}$

In this exotic treatment, the court adopts a negligence test for seats behind home plate that must be protected by a reasonably safe screen, but retains the traditional "assumption of risk" rule for all other areas in the ballpark, except possibly on days when the home plate sections are filled because the Mets are in the World Series or Dwight Gooden is pitching. ${ }^{188}$ Yet, as Chief Judge Cooke noted in dissent, ground-level box seats may be equally or more dangerous than some areas located behind home plate. ${ }^{189} \mathrm{He}$ also observed that spectators may not be aware of "an unusually high incidence of injuries" in a particular seating area, which would preclude an informed choice between greater safety or unobstructed views. ${ }^{190}$ Judge Cooke concluded that the plaintiff should be allowed the opportumity to prove she was subjected to an unreasonable risk in the seat the Mets assigned her. ${ }^{191}$ As an alternative to a negligence standard, the plaintiff's attorney argued on an enterprise liability rationale that the loss should be spread across all Mets customers. ${ }^{192}$

185. Id.

186. Id. at 998,463 N.E.2d at 1220,475 N.Y.S.2d at 368 .

187. Id. at 997-98, 463 N.E.2d at 1220, 475 N.Y.S.2d at 368 (quoting Akins v. Glens Falls City School Dist., 53 N.Y.2d 325, 331, 424 N.E.2d 531, 534, 441 N.Y.S.2d 644, 647 (1981)).

188. See id. at 999-1001, 463 N.E.2d at 1221-22, 475 N.Y.S.2d at 369-70 (Cooke, C.J., dissenting).

189. See id. at 1000,463 N.E.2d at 1221, 475 N.Y.S.2d at 369 (Cooke, C.J., dissenting).

190. Id.

191. See id. at 1001,463 N.E.2d at 1222,475 N.Y.S.2d at 370.

192. The plaintiffs attorney argued: "It isn't fair that one person should get an eye injury or fractured skull so that the rest of us can enjoy the national pastime." Margolick, Girl Hurt at Shea Seeks \$2.7 Million and Fan Safety, N.Y. Times, July 31, 1982, at 29, col. 1. 
The Davidoff opinion rejected this approach on the ground that it "would require a baseball field proprietor to operate as an insurer of spectators unless there was a protective screen shielding every seat. . . . [A] proprietor should be allowed to satisfy the desires of the many spectators who prefer to view the game from a seat unobstructed by fences or protective screening."193

Aside froin an enterprise liability "fairness" argument, which is not especially persuasive in this case, ${ }^{194}$ there are four reasons why imposition of strict liability on operators of large sports arenas would be preferable to either a negligence or "assumption of risk" treatınent. First, under any loss-allocation doctrine except strict hability, the responsibility to determine the severity and probability of spectator injuries in particular locations is diffuse. The cumulative magnitude of accident losses is fundainental to any decision whether precautionary measures should be adopted in specific circumstances. No spectator could acquire actuarial data on the incidence of serious injuries. Yet, as Judge Cooke recognized, arena patrons must know the risks to which they are exposed before they could decide whether to prefer additional safety or unobstructed seats. Judge Cooke failed to realize, however, that the same problem would arise under a negligence test because typical spectators do not know the chance of thei: encountering a "reasonable" risk. Only the arena operator, not spectators or ballplayers or judges, is in a position to acquire data on aggregate losses in varying locations within each stadium, but the operator has little incentive to do so under current legal doctrines. Indeed, were the arena owner to assemble data on accident probabilities, that information could greatly facilitate neghigence actions brought by injured spectators.

Second, contrary to the Davidoff court's assertion, strict hability would not preclude arena operators from offering unobstructed views to their patrons. Rather, the operator would balance the risk of injury in particular locations against the costs of protection and the possible loss of customers if obstructions were created. This is precisely the task a court must acconiplish under a negligence standard, but arena operators are generally more coinpetent than judges to decide whether additional investments should be made in precaution or insurance. Operators would, if strictly liable for accident losses, examine relative costs and benefits on a recurring basis; they are better informed about potential preventive measures; and they can better estimate the patronage that

193. 61 N.Y.2d at 998,463 N.E.2d at 1220,475 N.Y.S.2d at 368 .

194. Everyone creates some risks and is exposed to others. It is unlikely that the risks associated with watching events in major sports arenas are so distinctive that these risks must "fairly" be imposed only on arena customers, while thousands of equally severe risks are spread across the population as a whole through social insurance systems. Moreover, social imsurance could be as effective as enterprise liability from a "deep pocket" perspective. 
might be lost if those measures were implemented. Moreover, strict liability would greatly ease the evidentiary problems of plaintiffs, who typically have less access to relevant information, and it may reduce the transaction costs associated with tort litigation. ${ }^{195}$

Third, even if typical spectators "could be" the cheapest cost avoiders for arena accidents, strict liability on operators would create a greater marginal deterrent incentive than would any doctrine that allocates losses to customers. As discussed in Part I, spectators have strong nonlegal incentives to protect themselves, their behavior is seldom guided by an appreciation of applicable legal rules, and arena accidents usually result from periodic inattention rather than inefficient deliberate choices. ${ }^{196}$ Apart from injuries caused directly by balls striking spectators, accidents can occur when people charge through the stands or fall over railings while attempting to retrieve nearby balls. If arena operators beheve precaution is worthwhile in light of cumulative accident losses, they could redesign the playing field to increase the distance between batters and patrons, and they could also install protective measures like screens, transparent partitions such as those used in hockey and jai alai arenas, nets or platforms to catcli customers who lose their balance, section dividers to restrict crowd movements, wider aisles, or better lighting. Whether any of these preventive measures would be cost-justified in particular circumstances is precisely the sort of issue that problem-solving arena owners are best able to address. Current legal doctrines do not create a strong incentive for stadium owners to protect inattentive or careless spectators against accidents that may occur with considerable frequency. Yet neghigence and "assumption of risk" doctrines do not, in reality, provide a significant marginal incentive for spectators to protect themselves. If strict hability would induce arena operators to install safety measures whenever they believe accident costs exceed prevention costs, but would not appreciably reduce nonlegal spectator incentives to avoid injuries, then strict liability appears preferable to current doctrines from a social engineering perspective.

An important final consideration is that strict liability will induce arena operators to insure against spectator injuries that cannot feasibly be avoided, and this insurance will reduce secondary accident losses or dislocation costs. Negligence and "assumption of risk" doctrines often

195. This observation is limited to the litigation costs of each case. Judge Posner lias noted that strict liability could incrcase net transaction costs because a greater number of cases may be brought. See Posner, supra note 14, at 209. This may or may not occur in a particular accident setting because the greater certainty associated with a strict liability rule may induce settlements more frequently than increased litigation. See Rizzo, supra note 123, at 317-18. Litigation or settlement costs in particular accident contexts inust also be offset against the transaction costs associated with recoveries by victims under liealth or social insurance programs.

196. See supra text accompanying notes 58-63. 
allocate losses to victims, such as the child in Davidoff, who may not be adequately insured. More than ten percent of the American population, for example, has no health coverage, ${ }^{197}$ and a larger percentage may not have substantial protection against long-term disability and lost income. Sporting events attract a cross-section of the population including large numbers of children, old people, and poor people who are characteristically underinsured. How much insurance should be provided is partly a function of the probability and severity of spectator injuries, and that information is more readily available to arena owners than to their patrons. The Davidoff opinion stated in a conclusory manner that arena operators are not "insurers" of spectator safety, ${ }^{198}$ but a social engineering analysis suggests that they should be. If cumulative losses at sports arenas are not high, a requirement that arena operators insure against spectator injuries will not substantially raise the price of the activity. If cumulative losses are high, the imposition of strict hability would create an effective incentive for arena operators to prevent injuries when feasible and to provide insurance for unavoidable injuries.

\section{Intentional Torts}

As a prerequisite for intentional tort liability, the Restatement (Second) of Torts and Dean Prosser's treatise indicate that a party must intend not only an act but also the consequences substantially certain to result from that act. ${ }^{199}$ This doctrine is generally coinpatible with my emphasis on the decisionmaking characteristics of the actors. When a person genuinely understands the probable consequences of his risk-creating choices, he frequently would be able to assess whether the benefits of those choices exceed their social costs. If the potential mjurer is a meinber of a class of actors whose behavior is normally responsive to costs imposed by legal rules, ${ }^{200}$ then assignment of hability on an intentional tort theory will encourage the typical actor to make cost-minimizing decisions without regard to which party suffers the loss. An intentional injurer will be liable for the consequences of his actions and hence has no incentive to distort loss-avoidance decisions on the basis of distributional considerations as he would under a negligence standard. ${ }^{201}$

197. See Bovbjerg, Competition Vcrsus Regulation in Medical Care: An Overdrawn Dichotomy, 34 VAND. L. Rev. 965, 965 n.2 (1981) (citing Health INsurance INSTItute, Source Book of Health INSURANCE DaTA 11 (1979-1980)).

198. See Davidoff, 61 N.Y.2d at 998,463 N.E.2d 1220, 475 N.Y.S.2d at 368.

199. See Restatement (SeCOND) OF TORTS § 8A (1965); Prosser \& KeEton, supra note 48, at 34-36.

200. Intentional tort theories have often been applied in cases where the defendants are children or are insane, and where the resulting loss allocations are unlikely to have any social engineering effects on the behavior of comparably situated actors. See, eg., McGuire v. Almy, 297 Mass. 323, 8 N.E.2d 760 (1937); Brown v. Dellinger, 355 S.W.2d 742 (Tex. Civ. App. 1962).

201. Under a negligence test, the defendant will not bear any of the plaintiffs losses if a court 
In many of these settings, typical victims would not anticipate intentionally harmful conduct and would therefore be unable or unlikely to protect themselves. ${ }^{202}$ Thus, many intentional torts entail unilateral problem-solving risks, and the legal inquiry into the injurer's state of mind can be viewed as a means to determine whether the actor is really an informed problem solver for the risk he created.

In practice, many courts have imprecisely applied intentional tort doctrimes in cases where injurers could not foresee the consequences that flowed from their acts. In Vosburg $v$. Putney, ${ }^{203}$ for example, an elevenyear-old boy lightly kicked a schoolmate's leg while they were seated in a classroom. The victim had previously been injured in the saine spot and the kick induced deterioration that led to a permanent loss of function in the leg. The jury found that the kick was the "exciting cause" of the injury, but also that the defendant did not intend to harm his classmate. ${ }^{204}$ Nonetheless, the court held the defendant liable because he intended an "unlawful" act that caused the plaintiff's injury. ${ }^{205}$ This doctrimal approach stressed the retrospectively-determined legality of the imtentional act, rather than whether the injurer intended the consequences that occurred or, indeed, any significant physical consequences. It is difficult to see how social engineermg tort goals are promoted by such a treatment. Aside from the fact that children seldom pay attention to liability rules, no actor could conduct a meaningful cost-benefit analysis in circumstances where the consequences of the intended act are unforeseeable and wholly disproportionate to any harm that could be anticipated. Holding the mjurer im Vosburg liable on an intentional tort theory is unlikely to have any effect on the behavior of similarly situated actors.

Social engineermg goals are not, of course, the only legitimate tort

determines that his behavior is reasonable. Under an intentional tort treatment, the defendant will be liable for the plaintiff's losses whether or not his decisions are reasonable from a social perspective. Because the defendant can avoid all liability under a negligence approach, and because therc is frequently soine uncertainty about whether a court will categorize particular behavior as reasonable or unreasonable, a negligence treatınent unay encourage potential injurers to call close questions in their own favor when making cost-benefit assessinents. Under an intentional tort analysis, the mjurer will have to bear the loss regardless of whether he or the victiun suffers it initially, and hence distributional considerations should not tend to distort his cost-benefit calculations in problematic cases.

202. This is often but not always true. Vincent v. Lake Erie Transp. Co., 109 Minn. 456, 124 N.W. 221 (1910), is an illustration where potential victims inay be able to anticipate and guard against intentionally larmful behavior by others. See supra text aecompanying notes 130-33.

203. 80 Wis. 523, 50 N.W. 403 (1891).

204. Id. at $524,50 \mathrm{~N} . \mathrm{W}$. at 403 . These findimgs were rendered as part of a special verdict.

205. The court held "that plaintiff inust show either that the intention was unlawful, or that the defendant is in fault. If the intended act is unlawful, the intention to commit it must necessarily be unlawful. Hence, as applied to this case, if the kicking of the plaintiff by the defendant was an unlawful act, the intention of defendant to kick him was also unlawful." Id. at 527, 50 N.W. at 403. 
objectives, and perhaps the result in Vosburg can be rationalized on corrective justice grounds. Yet "fairness" or other corrective justice arguments should be applied in a cogent and consistent fashion. Courts have often refused to impose liability when high accident losses do not appear commensurate with the defendant's degree of culpabihity. ${ }^{206}$ Under this equitable principle, the trivial misconduct by the injurer in Vosburg arguably should not expose him to liability for unforeseeable losses. Indeed, the court itself observed: "It is a peculiar case, an unfortunate case, a case, I think I am at liberty to say, that ought not to have come into court. The parents of these children ought, in some way, if possible, to have adjusted it between themselves."207 I believe this type of unforeseeable accident loss would be allocated more equitably through social insurance programs than through intentional tort liability.

In other accident contexts, the courts have applied a negligence standard rather than an intentional tort theory because they thought the injuries were not "substantially certain" to occur. ${ }^{208}$ This doctrinal requirement often reflects a confusion between true uncertainty and stochastic risks. ${ }^{209}$ When a common activity produces injuries with sufficient frequency that a rehable probability distribution can be determined on an actuarial basis, a problem-solving actor may be uncertam which specific victims will be harmed and yet would be "substantially certain" that a significant number of people will be mjured through the choices he makes. When electric generators emit ashes and particulate matter, for example, utilities know that these pollutants will cause respiratory problems for old people and other sensitive populations. When automobile manufacturers choose not to provide impervious gas tanks, they know a certain number of vehicles will be involved in accidents where the tanks will be punctured and preventable fires will ensue. These decisions may well be reasonable from a cost-benefit perspective, but the absence of knowledge about the identities of specific victims does not make resulting accident losses any less "intentional" than the damage in Vincent or many other cases where the reasonableness of the defendant's actions has been considered legally irrelevant. A focus on the problem-solving attributes of the parties would reduce the need for questionable judicial

206. See, e.g., Prosser \& KEETON, supra note 48, at 287, 312; Calabresi, supra note 108, at 101-02 \& n.50.

207. Vosburg, 78 Wis. $84,86,47$ N.W. 99,99 (1890).

208. See Prosser \& KeETON, supra note 48 , at $34,36$.

209. Stochastic risks are those for which a reliable probability distribution is available but there is uncertainty about the results in each particular instance. See generally K. RADFoRD, supra note 40 , at 59-61 (1975). Where a reliable actuarial history can be derived, the likelihood and average magnitude of harm is relatively certain even though the identities of the victins cannot be ascertained in advance. See, e.g., Grady, supra note 3, at $808 \mathrm{n} .26$ ("An injurer who is involved in very large numbers of accidents (for example, an ąuto manufacturer) will often estimate expected harm before an accident with practically the same aceuracy as a court after an accident."). 
distinctions that currently arise in intentional tort analyses, such as those between "unlawful" and intended consequences or between "substantially certain" and stochastically certain risks. "Intent" should simply be treated as one form of evidence that the actors really are problem solvers capable of making informed risk-avoidance decisions.

\section{Allocation of Automobile Losses}

Under the proposed hierarchical approach to loss internalization, courts or legislatures should assign automobile accident costs to manufacturers because they are problein-solving actors with respect to autoinotive safety decisions while drivers typically are not. Strict liability would induce producers to install airbags or alternative passive restraints, more durable structural frameworks, puncture-resistant gas tanks, drunkard-proof ignition systems, and many other potentially feasible safety features. ${ }^{210}$ I am sure Professor Calabresi would agree that allocation of losses to manufacturers will strengthen their incentive for risk-avoidance decisionmaking and that internalization on drivers does not significantly affect the driving behavior of most people. Calabresi's preference for first-party insurance is partly based on his assumption that insurance premiums tailored to high-risk classes of drivers decrease the level of "risky" driving and related accident losses. ${ }^{211}$ In other words, Calabresi apparently believes that price-avoidance behavior by high-risk drivers will achieve equal or better accident cost reduction than would strict product liability. This premise is unrealistic for several reasons.

The extent of price-avoidance behavior by "low-attention" drivers is dependent on the relative magnitude of driving costs under alternative liability systems and on the price elasticity of driving. Calabresi's analysis implicitly assuines that a substantial number of high-risk individuals, who are currently deterred by marginal insurance rates, could afford to drive under a inanufacturer liability system. ${ }^{212} \mathrm{He}$ notes that premiums

210. An important advantage of strict product liability over either regulatory or judicial determinations of whether product designs are reasonably safe is that decentralized manufacturers arc typically in the best position to decide which specific preventive measures are feasible and to develop better devices. See generally Calabresi, supra note 3, at 669-71; Calabresi \& Hirschoff, supra note 14, at 1060-61, 1074-76. I believe Calabresi's preference for first-party driver insurance rather than manufacturer liability is inconsistent with his emphasis in other essays on which category of party is the better risk-avoidance decisionmaker. See Calabresi \& Hirschoff, supra note 14, at 1071; supra text accompanying notes 115-17.

211. See Calabresi, supra note 64 , at $839 \&$ n.23, 843.

212. See id. at $841-42$. The thrust of Calabresi's distributional argument is that the current third-party approach imposes unfairly high losses on young, old, and poor drivers, all of whom may also be high-risk drivers. See id. at 842-44. Because these same classes of drivers may all have comparatively high accident rates and high third-party insurance premiums, it is probable that a shift from a third-party to a first-party system would not raise the insurance costs of high-risk drivers. Calabresi's proposal therefore would not deter a larger number of high risk drivers than are currently deterred by third-party insurance premiums. If that assumption is correct, then we can 
in one state are roughly three times higher for unmarried 16-20 year-old drivers ( $\$ 169 / 6$ months) than for married people over 25 ( $\$ 60 / 6$ months), and he characterizes these high-risk rates as "exorbitant, indeed almost exclusionary."213 Yet Calabresi presents no evidence that highrisk premiums deter many young people from driving. Even the highest rate category is much less expensive than the annual costs of purchasing, maintaining, and operating a motor vehicle. Moreover, the rise in vehicle prices resulting from manufacturer liability would partly offset the savings realized by high-risk drivers through the elimination of riskrelated insurance premiums. ${ }^{214}$ When the cumulative costs of driving are considered, a shift from a driver liability system to manufacturer liability would probably not lead to a significantly greater level of high-risk driving. ${ }^{215}$ In contrast, a strict product liability system would clearly induce a greater level of vehicle safety and a corresponding reduction im accident losses.

It is also unlikely that driving exhibits a high degree of price elasticity in response to variable insurance rates. Most states require some form of automobile insurance before people can drive at all, which presents high-risk drivers with a binary choice-either purchase coverage or refrain from driving. Some driving may be sucli an essential activity in our society that few people would be deterred by insurance costs unless rates were truly prohibitive. In most areas including Iowa, the state cited by Calabresi in his essay, abstaining from driving would leave young people virtually immobile, and they would presumably forego many other activities before they choose to stop driving. If the demand for "some" driving and hence for liability insurance is relatively melastic, a first-party system will not deter mucl risky driving. Because insurance premiums, unlike gasoline or vehicle maintenance costs, are not propor-

roughly compare the estimated present level of high-risk driving against the level likely under a product liability approach in order to assess whether manufacturer liability would really increase accident losses attributable to high-risk driving.

213. Id. at $839 \&$ n.23.

214. The level of high-risk driving is dependent on the total driving costs incurred by high-risk categories. If risk-related insurance premiums were eliminated, high-risk drivers would still bear part, although not as large a proportion, of net accident losses in the form of higher vehicle prices. Calabresi largely dismisses the possibility that manufacturers might charge high-risk owners higherthan-average car prices. See id. at 839 . While they could not achieve an ideal level of price discrimination, I believe producers would be able to tailor prices to risks in some measure. See infra text accompanying notes 218-19.

215. As an illustration, assume that insurance rates vary between $\$ 340$ and $\$ 120$ per year (Iowa's rates as cited by Calabresi, see supra note 64 at $839 \mathrm{n.23}$ ) and that the annual costs of owning and operating a vehicle are $\$ 2500$, exclusive of insurance costs. Under a risk-related driver liability system, total driving costs for a high-risk driver would be $\$ 2840$ compared to $\$ 2620$ for the low-risk driver. Under a product liability approach in which manufacturers attempt no price discrimination, the total cost to all drivers is likely to be about $\$ 2700$ (because there are a larger number of low-risk than high-risk drivers). I believe it implausible that the marginal difference between $\$ 2700$ and $\$ 2840$ would lead to a substantial increase in high-risk driving if product liability is imposed. 
tional to the volume of driving, a first-party system would create little incentive for price-avoidance behavior once high-risk drivers obtain coverage. Calabresi's description of current rates for young drivers as "almost exclusionary"216 is insufficient from a social engineering perspective; any driver liability system must actually exclude high-risk drivers in order for price-avoidance behavior to achieve sigmificant accident cost reduction. Thus, Calabresi's assumption that first-party insurance would effectively deter much high-risk driving is implausible.

If risk-related insurance premiums did induce price-avoidance behavior by drivers, the resulting choices might not reduce net accident losses. Instead, people's demand could shift from one risky activity to an even more hazardous substitute activity. ${ }^{217}$ To compensate for high insurance premiums, high-risk drivers may simply purchase lower coverage and consequently increase the chance of dislocation costs. High-risk drivers under a driver liability system inay also decrease expenditures for vehicle maintenance, may extend the use of older cars, and may purchase smaller models that are more vulnerable in crashes. Moreover, young people who are deterred from driving by risk-related premiums may instead hitchhike or ride motorcycles, but these substitute activities are not clearly safer than driving. These kinds of counterproductive demand shifts may also occur when manufacturers raise automobile prices in response to the imposition of strict product liability. Nevertheless, manufacturers could, and often would, directly reduce accident losses through the installation of more effective safety devices, whereas the only deterrent effect of loss internalization on "low-attention" drivers would be to induce price-avoidance behavior that may not decrease net accident costs.

Calabresi assumes that first-party insurance rates would be tailored to the risks created by different classes of drivers, ${ }^{218}$ but that manufacturers under a product liability regime could not achieve a somewhat comparable level of discrimination in their pricing policies. Under strict liability, producers almost certainly would raise the prices of high-powered "muscle" cars, sports cars, and subcompact models that especially appeal to young drivers and that have relatively bad accident histories. Manufacturers would be best able to determine whether a high incidence of accident losses is attributable to the dangerous propensities of the vehicle itself or to the types of drivers likely to purchase the model. This determination would enable manufacturers to make more efficient investments in either safety equipment or additional insurance. Because cars

216. See id. at 839 .

217. See generally Henderson, Extending the Boundaries of Strict Products Liability: Implications of the Theory of the Second Best, 128 U. PA. L. REv. 1036 (1980).

218. See Calabresi, supra note 64 , at $839,840-41,843$. But see supra notes $71-72$. 
are most often driven by their owners, producers could also tailor prices to some degree based on the age or other characteristics of risky categories of purchasers. ${ }^{219}$ I do not contend that the price-avoidance effects of product liability and first-party systems would correspond precisely, but rather that manufacturers under a strict liability rule would have a mucl greater incentive than at present to increase prices for high-risk vehicles and high-risk purchasers. Thus, the imposition of product liability would engender considerable price-avoidance behavior ${ }^{220}$ as well as the exphcit risk-avoidance decisionmaking tliat I believe should be emphasized.

Finally, I have confidence that a legal focus on the presence or absence of problem-solving behavior would be far more admimistrable than the speculative price-avoidance analysis necessary under Calabresi's treatment of automobile accident losses. Calabresi has often argued that judges and legislators can more reliably identify the category of actors who are the best decisionmakers than the particular decision which would be most efficient. ${ }^{221}$ Yet, he adopts exactly the opposite approach in his discussion of automobile accidents: "[a]n appropriate analysis of the choice among systems would . . . compare the safety inducing potential of each approach when aided by whatever governmental regulations it needs to fill in its lacunae."222 I question the wisdom of requiring legal decisionmakers to "compare the safety imducing potential" of competing hability systems in accident settings where behavioral interactions are complex and often subtle, and where many alternative means may be available to reduce net accident losses. Under my recommended treatment, legal decisionmakers need only determine tliat manufacturers are problem-solving actors for most automobile accident contexts while drivers typically are not. The resulting strict product liability rule would then encourage decentralized problem-solving producers to assess for themselves the "safety imducing potential" of a multitude of possible precautionary measures.

219. Aside from data on the age and sex of purchasers, manufacturers could by contract require the provision of accurate information about prior accidents and traffic violations in the same way that insurance companies are largely dependent on data supplied by policyholders. Young high-risk drivers could evade manufacturer attempts at price discrimination if they arrange to have parents or another low-risk person buy the vehicle. Driver insurance systems, however, are also subject to manipulation because young people may either register cars in their parents' names or in locations different from the primary places of use. On balance, I suspect the incidence of "cheating" would be worse under a product liability regime (if producers try to discriminate based on driving risks) than under a driver insurance system. I do not, however, think that the possibility of evasion would preclude all atteinpts at price discrimination by producers.

220. See G. Calabresi, supra note 1 , at 171 n.29.

221. See Calabresi, supra note 3, at 666-70; Calabresi \& Hirschoff, supra note 14, at 1060-61, 1076.

222. Calabresi, supra note 64 , at 847 . 


\section{Contributory Negligence and Product Liability}

A number of legal rules require designated actors to protect potential victims against their own foreseeable careless behavior, and consequently preclude the defense of contributory negligence when plaintiffs fail to exercise reasonable care. In some jurisdictions, for example, railroads must maintam their brakes properly to protect those who carelessly become stuck at track crossings; ${ }^{223}$ employers who do not provide safety harnesses for window washers cannot escape liability on the ground that reasonable washers would refuse to work without safety equipment; ${ }^{224}$ promoters of unlicensed boxing matches cannot plead consent as a defense when a boxer is injured in a bout; ${ }^{225}$ and property owners responsible for maintenance of sidewalks cannot raise the contributory neghigence of drunken or inattentive pedestrians who fall into unprotected holes in the pavement. ${ }^{226}$ The deterrence created by these doctrines would be eroded if defendants could avoid liability by pleading the existence of the very behavior they should anticipate and guard agamst. These precautionary doctrines are currently the exception rather than the norm, but I believe their underlying principle should be widely applicable in unilateral problein-solving contexts. When some categories of actors are capable problem solvers with respect to a particular kind of risk and other parties typically are not, the proficient decisionmakers should be required not only to behave efficiently themselves but also to protect likely victims against the victims' foreseeable carelessness.

There are several reasons why this treatment should be adopted in the area of product liability. Manufacturers generally have much more expertise in risk-avoidance decisionmaking. If motivated by liability, they frequently could collect actuarial data on losses resulting froin different kinds of product inisuses in order to determine whether prevention or insurance is more efficient in specific accident contexts. Incorporation of safety features in product designs could prevent many injuries resulting from periodic inattention during misuses, perhaps the most common cause of product-related injuries. Some products are inore difficult to misuse or more tolerant of mishandling, and liability would provide competitive advantages for safer products if misuses lead to substantial accident losses. Potential victims have strong nonlegal incentives to avoid accidents whether they stem froin intended uses or product misuses, but, absent legal liability, the nonlegal incentives for manufacturers to prevent

223. See Prosser \& Keeton, supra note 48 , at 468 \& nn. 47-48.

224. See Osborne v. Salvation Army, 107 F.2d 929 (2d Cir. 1939).

225. See Hudson v. Craft, 33 Cal. 2d 654, 204 P.2d 1 (1949).

226. See Robinson v. Pioche, Bayerque \& Co., 5 Cal. 460 (1855). 
injuries from misuses are weak. ${ }^{227}$

Strict liability doctrines in many jurisdictions ostensibly require manufacturers to protect consumers against foreseeable misuses when they can feasibly do so, but few if any courts have restricted the defense of contributory negligence to the degree recommended here. Section $402 \mathrm{~A}$ of the Restatement precludes the defense when a user unreasonably fails to discover a product defect, but allows the defense if he "voluntarily and unreasonably" proceeds "to encounter a known danger."228 In Cepeda v. Cumberland Engineering Co. ${ }^{229}$ the New Jersey Supreme Court adopted the Restatement treatment where the victim lost several fingers when he operated a machine tool from which the hand guard had been removed. The court found the machine was defective in not having an interlock device that would prevent operation when the guard is off, but the case was remanded for a new trial on the issue of contributory negligence because the plaintiff knew the guard was missing while he ran the tool. ${ }^{230}$ In Suter v. San Angelo Foundry \& Machine Co. ${ }^{231}$ another hand-in-the-inachine case, the court overruled Cepeda and held that an einployee who inisuses equipinent in a foreseeable manner cannot be contributorily negligent because, as a matter of law, his behavior should not be regarded as "voluntary."232 The Suter opinion concluded that: "The defendant manufacturer should not be permitted to escape from the breach of its duty to an employee while carrying out his assigned task under these circumstances when observance of that duty would have prevented the very accident which occurred."233 Yet, the court did not exclude the defense of contributory negligence in other accident contexts where the installation of feasible safety devices would prevent product users from voluntarily and unreasonably encountering a known risk.

227. The manufacturer's principal nonlegal incentive is usually a desire to increase sales by offering relatively safe products to consumers who value safety. Advertising is the primary device manufacturers use to inform consumers about salient product attributes, and particularly about characteristics such as safety that are not immediately apparent from inspection of the products. There are numerous reasons why producers may be reluctant to disclose product-related safety hazards even when their goods are relatively safer than competing products. See, e.g., Latin, supra note 29, at 218-22; Posner, supra note 14, at 211; Schwartz \& Wilde, supra note 5, at 1429. I believe manufacturers would be especially unlikely to stress misuse-related risks in advertising because, at the time of sale, consumers typically would not expect to misuse the products and would seldom regard a competing good as "inferior" because it is more prone to accidents when misused. Advertisiug is expensive, the amount of information that can be communicated is himited, and manufacturers would generally find it more profitable to emphasize soine positive attribute of their goods rather than the propensity for misuse-related injuries.

228. RESTATEMENT (SECOND) OF TORTS $§ 402 A$ comment n (1965).

229. 76 N.J. 152, 386 A.2d 816 (1978), overruled by Suter v. San Angelo Foundry \& Mach. Co., 81 N.J. 150, 406 A.2d 140 (1979).

230. See id. at $180-82,386$ A.2d at $829-31$.

231. 81 N.J. 150, 406 A.2d 140 (1979).

232. See id. at 165-68, 177, 406 A.2d at 147-49, 153.

233. Id. at $168,406 \mathrm{~A} .2 \mathrm{~d}$ at 148 . 
The appropriate social engineering treatment of contributory negligence should depend on an assessment of the predominant causes of accident losses associated with product misuse. A purchaser inay realize he is misusing a product in a way that entails some risk, and yet may not understand the extent of the risk. When the misuse is foreseeable and occurs frequently, the manufacturer would usually be able to identify the magnitude of the risk and whether it warrants feasible preventive measures. If most accidents result from momentary inattention during periods of misuse, the primary cause of losses is not "voluntary exposure" to a "known risk" but rather the inability of people to maintain continuous vigilance while engaged in risky activities. If the victim in Cepeda, for example, had been a self-employed machine tool owner, and hence under no compulsion to use the equipment without a finger guard, he may still have misused the machine and been injured as a result of inattention. From the perspective of efficient risk avoidance, the saine interlock device that would protect inattentive employees would also prevent injuries to owners who voluntarily operate the machine in an unwise manner. When the known risk involves the possibility of death or serious injury, I do not find credit the "moral hazard" claim that manufacturer liability would significantly induce purchasers to endanger theinselves through product misuses. ${ }^{234}$ The imposition of liability on product misusers will have little marginal deterrent effect, but assignment of liability to manufacturers would encourage them to prevent misuse-related losses when prevention costs are less than accident costs. If the majority of these accidents stem from periodic inattention or from consumer ignorance about the magnitude of product misuse risks, then the same policies that preclude the defense of contributory negligence for careless authorized uses should also apply to foreseeable misuses. Contributory or coinparative neghigence should remain a valid defense only in cases of deliberately self-inflicted harm, a narrower ground than in current product liability treatments. ${ }^{235}$

234. See Schwartz \& Wilde, supra note 5, at 1446-47. See generally Polinsky, Economic Analysis as a Potentially Defective Product: A Buyer's Guide to Posner's Economic Analysis of Law, 87 HARV. L. REV. 1655,1671 n.88 (1974).

235. The logic of this argument might be carried further in that manufacturers in some risk contexts could be required to protect people against deliberately self-inflicted harm. In most settings, people who are determined to injure themselves could circumvent feasible safety measures, which means those measures would seldom prove cost-effective. There are, however, some contexts where intentional misuse is foreseeable- the use of "diet pills" and model airplane glue as drugs, for example -and where liability might induce manufacturers to reduce the hazardous propensities of their products. A hine must be drawn somewliere and, for purposes of this analytical sketch, I lave drawn it between voluntary misuse and deliberately self-inflicted harm; nevertheless, a more complete analysis should consider diverse types of products and product-related risks on the basis of their distinctive characteristics. 


\section{Risk-Related and Social Insurance Systems}

FIGURE 2

Risk Classes and Compensation Strategies

\begin{tabular}{|c|c|c|c|}
\hline $\begin{array}{l}\text { Classes } \\
\text { of Tort } \\
\text { Risks }\end{array}$ & $\begin{array}{l}\text { Problem-Solving } \\
\text { Risks }\end{array}$ & $\begin{array}{l}\text { High-Frequency, } \\
\text { High-Severity } \\
\text { Risks }\end{array}$ & $\begin{array}{l}\text { Other } \\
\text { Low- } \\
\text { Attention } \\
\text { Risks }\end{array}$ \\
\hline $\begin{array}{l}\text { Suggested } \\
\text { Compensation } \\
\text { Strategies }\end{array}$ & Tort Liability & $\begin{array}{l}\text { Risk-Related } \\
\text { (Tailored) } \\
\text { Insurance } \\
\text { If Feasible }\end{array}$ & $\begin{array}{l}\text { Social } \\
\text { Insurance } \\
\text { Systems }\end{array}$ \\
\hline
\end{tabular}

The multitude of discrete accident contexts may be depicted on a continuum in which three general classes of risks can be distinguished: "high-attention" risks characterized by unilateral or bilateral problemsolving behavior; a limited but important group of "low-attention" risks marked by both a high frequency and high severity of accident losses; and a vast array of "low-attention" risks that cannot be conveniently distinguished on the basis of net accident losses. Litigation is a very expensive method for accident loss allocation, and the transaction costs of the tort system would not be warranted unless liability achieves some commensurate increase in social utility. I have argued to this point that liability rules promote efficient behavior modification only in "highattention" risk contexts where at least one category of actors is adept at problem-solving. There are many alternative compensation systems that could be employed in "low-attention" contexts to accomplish loss spreading and occasional marginal deterrence with reduced transaction costs. At a high level of generality, accident losses can be distributed through social insurance programs or through compulsory insurance on the activities and actors that create specific "low-attention" risks. The following discussion describes the relative advantages of risk-related insurance and social insurance strategies.

Tort liability or risk-related insurance would be less efficient than reliance on social insurance programs in the majority of "low-attention" contexts because litigation and "tailored" insurance systems typically entail high transaction costs, and because legal decisionmakers frequently could not determine which of many risky activities should be charged with particular accident losses. ${ }^{236}$ In Brown v. Kendall, ${ }^{237}$ for example, the defendant unintentionally struck the victim's eye while 
swinging a stick in an atteinpt to separate two fighting dogs. During the melee the dogs shifted their positions, the defendant owner of one of the dogs retreated a few steps, the plamtiff who owned the other dog moved forward a few steps, and the defendant's stick hit the plaintiff (or the plaintiff's eye hit the stick). The court's decision became famous because it was among the first to adopt a negligence standard instead of a strict liability trespass rule for injuries "directly" caused by the defendant's actions. ${ }^{238}$ Yet, from the perspective of behavior modification in similar circumstances, neither a negligence treatment nor strict liability is likely to influence the actions of animal owners when their pets are endangered. This injury occurred because botll actors paid attention to their dogs rather than to each other's positions at the critical moment, and I believe no hability rule could significantly affect the focus of attention during perceived emergencies. Thus, tort hitigation achieves little or no deterrence in a case like Kendall.

It is also unclear which activity in Kendall should bear the loss if risk-related insurance is required. Dog owners, fight stoppers, stick wielders, and onlookers all create soine risks, but those risks are not substantially greater in kind or degree than the risks associated with many thousands of other activities. Neither actor is clearly a inore appropriate locus for loss internalization in this context because the behavior of both parties contributed to the accident and either could have avoided it with equal ease had lie paid attention to the right risk at the right time. Moreover, neither the class of potential injurers nor the class of victims is likely to liave a significantly worse accident history on an actuarial basis with respect to this type of risk. The benefits that might accrue from risk-related insurance in the accident context presented in Kendall are not sufficient to warrant the higher transaction costs imposed by "tailored" systems.

Solne activities that contribute to frequent losses are clearly more dangerous and inore easily identified than others. Driving, for example, is riskier than walking, although both are nominal "causes" of accidents in whicl vehicles collide with pedestrians. The primary social engineering purpose of internalizing accident losses arising from especially dangerous "low-attention" activities is to raise the price and thereby decrease the frequency or intensity level of those activities. High riskrelated insurance premiums might induce demand shifts away from risky enterprises and toward substitute activities that entail lower social costs. $^{239}$ As one illustration, Professor Sugarman cites Grayston's find-

238. See Prosser \& KeETON supra note 48, at 163 .

239. In other words, risk-related insurance premiums may induce price-avoidance behavior, which in turn may lead to the substitution of safer activities for more hazardous ones. See supra text accoinpanying notes $108-13$. 
ing that the imposition of automobile insurance costs on drivers led to less driving and, in turn, to fewer accidents. ${ }^{240}$ Sugarman dismisses that study because it failed to show risk-related insurance produces 'better driving' behavior, ${ }^{241}$ but this response reflects his peculiar notion that deterrent measures are valueless unless they achieve nearly perfect deterrence. ${ }^{242}$ Accident losses associated with driving are extremely high, which suggests that "less driving" is likely on average to be "better driving" from society's perspective. ${ }^{243}$ Moreover, in competitive situations even partial internalization may create competitive advantages for safer actors or enterprises. ${ }^{244}$ The point of internalization through risk-related insurance in "low-attention" contexts is not primarily to encourage better risk-avoidance decisionmaking, but rather through price-avoidance decisions to shift demand toward activities or actors that generate lower accident costs.

The boundary between problem-solving behavior and mattentive behavior can be altered in some accident settings. People may occasionally pay attention to high insurance premiums and may attempt to reduce them through the exercise of greater care, when they would not be similarly motivated by the low-probability risk of serious accidents. ${ }^{245}$ Internalization through risk-related msurance may consequently induce some problem-solving behavior that would not result from reliance on either tort liabilty or social insurance systems. Contrary to Sugarman's all-or-nothing approach, internalization may be useful if it affects the inarginal risk-avoidance decisions of some people in especially hazardous accident contexts, even if risk-related insurance does not alter the typical behavior of a class of actors and would not transform the activity into a "high-attention" risk category. First-party automobile msurance, for instance, may reduce accident losses to some extent both by decreasing the amount of driving and by influencing the driving behavior of some people at the margin. This observation is not inconsistent with my prior treatment of automobile manufacturer liability; rather, it illustrates the recommended hierarchical approach to allocation of accident losses. I believe internalization of accident costs on problem-solving manufactur-

240. See Sugarman, supra note 21 , at 589 \& n.153 (citing Grayston, Deterrence in Automobile Liability Insurance-The Empirical Evidence, 1973 INs. CoUNS. J. 117.)

241. Id.

242. For my critique of Sugarman's analysis, see infra text accoinpanying notes 256-69.

243. Unfortunately, there is no assurance that risk-related insurance premiums will substantially reduce the amount of driving or net automobile accident losses. See supra notes 211-18 and accompanying text.

244. This inay be the effect, for example, of the limited insurance rating practices incorporated in most worker compensation programs. See Atiyah, Accident Prevention and Variable Premium Rates for Work-Connected Accidents (pt. 1), 4 INDUS. L.J. (U.K.) 1 (1975); see also Sugarman, supra note 21, at 613-16.

245. See Fleming, The Role of Negligence in Modern Tort Law, 53 VA. L. REV. 815, 825 (1967). 
ers would achieve greater marginal deterrence than any driver liability system, but the marginal price-avoidance incentives created by riskrelated insurance may be preferable to the absence of deterrence in social insurance programs. ${ }^{246}$

In situations where accident losses are severe, the deterrent benefits resulting from price effects and occasional improvements in risk-avoidance decisionmaking may outweigh even relatively high transaction costs. Some hazardous activities, such as the use of stairs, are probably too widespread for feasible risk-related insurance. ${ }^{247}$ Yet, other dangerous enterprises may have characteristics, such as a licensing requirement or a limited class of identifiable actors, that would permit insurance tailoring with manageable transaction costs. When the cost of rating mdividual actors on the basis of prior accident histories is prohibitive, it may nevertheless be desirable for losses to be internalized on the activity as a whole $\mathrm{m}$ order to promote the substitution of safer for riskier enterprises.

Legal doctrines have often been developed pragmatically in view of the comparative ease and lower cost associated with holding specified types of actors responsible for particular accident losses. As one illustration, commentators often discuss "driving" behavior and automobile insurance as if the two were necessarily related, but in reality it is owners rather than drivers who must insure. In Kalechman v. Drew Auto Rental, Inc. ${ }^{248}$ for instance, the court rejected the attempt of the rental car company to impute the driver's contributory negligence to a passenger partly on the ground that ownership of the vehicle provides the most rehiable basis for assuring that insurance will be available. ${ }^{249}$ Moreover, in some "low-attention" contexts the transaction costs associated with risk-related insurance could be reduced by redesigning the compensation system. A recent example is the partial shift from reliance on third-party insurance to first-party "no fault" automobile insurance.

Summers v. Tice ${ }^{250}$ illustrates a setting in which risk-related insurance would be preferable to either tort litigation or social insurance. In Summers, two hunters simultaneously shot in the direction of the victim and one of their shells seriously injured him. The victim, also a hunter,

246. See supra text accompanying notes $64-83,111-13$.

247. Falls, including those on stairs, are the most common cause of accidental deaths other than motor vehicle accidents. See National SafeTY Council, Accident Facts 9, 12, 80 (1980). Nevertheless, the use of stairs is ancillary to a wide range of activities, and I doubt that a feasible risk-related insurance scheme tailored to stairway accidents could be devised. The fact that riskrelated insurance is impracticable for some dangerous "low-attention" activities does not, however, suggest that tailored insurance systems cannot be useful in other high-frequency, high-severity risk contexts.

248. 33 N.Y.2d 397,308 N.E.2d 886,353 N.Y.S.2d 414 (1973).

249. Id. at 404,308 N.E. $2 \mathrm{~d}$ at 890,353 N.Y.S.2d at 419.

250. 33 Cal. 2d 80, 199 P.2d 1 (1948). 
was unable to identify which negligent actor caused the injury. The court shifted the burden of proof and held that the defendants would be jointly liable unless one of them could show he was not responsible for the accident. ${ }^{251}$ It is unlikely that this negligence treatment, or any tort liability doctrine, would affect the typical risk-avoidance behavior of other hunters in similar circumstances. Hunters seldom anticipate that they may accidentally shoot someone; there are strong nonlegal incentives for hunters to avoid shooting people; average hunters inay not know the applicable legal rules or may not consider them while engaged in the act of shooting; and hunting accidents usually result from inomentary inattention or from ignorance about safe practices in circumstances where typical hunters may not realize they are uninformed. ${ }^{252}$ Huntingrelated risks should therefore be regarded as "low-attention" accident contexts in which tort litigation would serve hittle social engineering purpose.

Risk-related insurance inay be worthwhile in this context because hunting is considerably more dangerous on average than are hiking, birdwatching, surveying, or many other outdoor activities that expose people to the risk of being shot. Demand for recreational experiences may be shifted from hunting to safer alternatives if losses are internalized on hunters. Unlike automobile accidents, where better safety equipment could substantially reduce the frequency and severity of injuries, the design of guns is clearly less important than the behavior of hunters in creating hunting-related risks. Varying insurance premiums rated on statistical accident propensities or individual accident histories may make the activity prohibitively expensive for especially risk-prone classes of hunters and may induce some inarginal risk-avoidance behavior in other hunters. Because hunting is a readily identifiable activity undertaken by a limited class of actors, the transaction costs of risk-related insurance should not prove excessive. ${ }^{253}$ In contrast, loss spreading through social insurance programs would not achieve any price-effect shifts to safer substitute activities nor any marginal risk-avoidance behavior in this unusually dangerous accident context.

Aside froin price-avoidance effects and marginal deterrence, distributional equity might be promoted if the parties who engage in especially risky activities are required to pay for the resulting losses. It is, of

251. See id. at 84-88, 199 P.2d at 3-5.

252. Imposition of losses on hunters through tort liability would only induce them to increase their knowledge of safe practices if they realize that their present level of knowledge is deficient. In reality, many hunters do not recognize their inadequate understanding of proper practices. See generally Bryant, Outdoors: Safety Advice for the Hunter, N.Y. Times, Dec. 10, 1984, at C11, cols. 1-3.

253. The issuance of hunting licenses could be conditioned on proof that each hunter has obtained insurance, in the samc way that registration of automobiles requires proof of insurance in many states. 
course, true that everyone creates some risks, and that transaction costs would prevent internalization of the losses associated with many activities. Nevertheless, it is not necessarily "unfair" to require that people bear the losses resulting from unusually risky enterprises simply because we cannot internalize all accident losses on all responsible actors. ${ }^{254}$ Even if reliance on social insurance is preferable to risk-related systems in the great majority of "low-attention" accident settings, legislatures or accident-prevention agencies should balance marginal deterrence and fairness considerations against transaction costs and competing fairness considerations in specific high-frequency, high-severity risk contexts. The choice between social insurance and risk-related insurance should turn on their comparative merits and feasibility in diverse accident contexts. Alternative compensation systems should not be contrasted at a high level of generality, as if we must adopt one approach or another for all "low-attention" accident losses. 255

\section{E. A Reply to Professor Sugarman's Critique}

The discussion and illustrations above emphasize the deterrent value of tort liability in accident contexts where one or more categories of actors are capable problem solvers. It must, however, be acknowledged that the prospect of liability often fails to create effective deterrent incentives. Professor Sugarman's essay in this Symposium correctly argues that liability rules frequently are too ambiguous or convoluted to provide guidance on acceptable modes of conduct, that tort law achieves too little deterrence in many accident contexts and too much in others, that victims receive too little compensation in some cases and too much in others, that tort litigation entails extraordinarily high transaction costs, and that inconsistencies abound. ${ }^{256}$ If the critical social policy question were whether tort liability is a perfect or nearly perfect mechanism for loss allocation, Sugarman's shotgun blast at tort law would be incontrovertible. Yet, his conclusion that the tort system is seriously flawed is

254. Sugarman advocates regulation rather than tort liability or risk-related insurance to achieve deterrence. Yet surely it is not "unfair" for society to regulate some extremely hazardous activities, and to impose regulatory costs on the responsible actors, just because we cannot regulate all activities that create some danger.

255. Professor Sugarman's critique of risk-related insurance, like his critiquc of tort liability, poimts out the inadequacies of this approach in many accident contexts and concludes that we should generally prefer social insurance systems. See Sugarman, supra note 21, at 573-81, 613-16, 621-22. As I emphasize below, the appropriate question is not whether risk-related insurance (or any loss allocation system) can function efficiently in all risk contexts, but whether a particular approach will best promote social engineering goals in specific accident settings. See infra text accompanying notes 260-69.

256. See Sugarman, supra note 21, at 559-617. For other generalized critiques of the deterrent value of tort hability, see Brown, Deterrence and Accident Compensation Schemes, 17 U.W. ONT. L. REV. 111, 113-23 (1978); Pierce, Encouraging Safety: The Limits of Tort Law and Government Regulation, 33 VAND. L. REV. 1281, 1283-1307 (1980). 
not, by itself, decisive or even very useful. A balanced analysis must ask, "Imperfect compared to what?" Our society currently relies on overlapping loss-avoidance incentives derived from three generic sources: deterrent incentives arising from market competition, ethical constraints, desires for self-protection, or other nonlegal considerations; incentives created by regulation; and incentives resulting from tort liability. Each of these deterrent systems is far froin perfect in practice, as Sugarman occasionally concedes. He nevertheless advocates that we discard one imperfect leg of our imperfect deterrence tripod and rely exclusively on the other two imperfect strategies.

Sugarman does not argue that nonlegal market incentives are sufficient by themselves to assure a reasonable level of risk avoidance; he instead emphasizes the utility of regulation, which ostensibly "renders superfluous much of tort law's deterrent potential."257 I believe this benign characterization of regulation stems from the familiar but unfortunate academic sport of contrasting the practical deficiencies of a real decisionmaking systein against the theoretical advantages of an idealized competing approach. ${ }^{258}$ One need not recapitulate the vast literature on the need for "regulatory reform" to demonstrate that regulations are often too ambiguous or convoluted to provide guidance on acceptable modes of conduct, that regulation often achieves too hittle deterrence or too much, that adminstrative compensation programs provide too hittle support for many beneficiaries and too much for others, that the regulatory process often imposes high transaction costs, and that regulation often produces inconsistent results. ${ }^{259}$ If typical tort judgments are too small to deter many defendants, as Sugarman contends, the same observation applies to the inodest fines levied for violations of most regulations. If insurance partly undermines the effectiveness of tort deterrence, indemnification clauses, insurance, and tax deductions also dilute the impact of many regulatory penalties. There is little reason to assume that people are ordinarily more familiar with the contents of the Federal Register and sinilar regulatory sources than they are with applicable liability doctrines, or that regulations are easier for average people to understand than tort rules. In short, virtually all of Sugarman's criticisms of the tort system might be, indeed liave been, directed at the inadequacies of regulation.

Dean Calabresi has contended that decentralized market actors, if

257. Sugarman, supra note 21 , at 564 .

258. For a similar criticism directed at the academic literature on "regulatory reform," see Latin, Ideal Versus Real Regulatory Efficiency: Implementation of Uniform Standards and "FineTuning" Regulatory Reforms (forthcoming in the Stanford Law Review, July 1985).

259. See, e.g., S. Breyer, supra note 29; G. Stigler, The Citizen and the State: Essays ON DEREgulation (1975); Wolf, $A$ Theory of Nonmarket Failure: Framework for Implementation Analysis, 22 J.L. \& ECON. 107 (1979). 
subject to tort liability, are usually better able than regulators to identify efficient loss-avoidance measures. ${ }^{260}$ Unlike Sugarman, Calabresi does not maintain thiat one system is invariably superior to the otlier, and I doubt that a comparative judgment at sucli a high level of generality lias any value at all. Tort liability may create more powerful incentives in some accident contexts; regulation may prove superior in otlers; but the combination of liability to encourage on-going precautionary efforts and regulation to control especially severe or widespread risks will frequently accomplisl better deterrence than could either alternative by itself. As a consequence of his universal condemnation of the tort system, Sugarman makes no attempt to discriminate between diverse risk categories where different liability and regulation strategies may offer comparative advantages. Althougli Sugarman and I agree that tort litigation is ineffective and unduly expensive in many accident contexts, my analysis points to situations in which problem-solving actors are likely to be influenced by tort liability. The fact that tort law does not promote social engineering goals in numerous accident contexts is liardly a justification for concluding that the tort system sliould be abandoned in all cases.

In several passages, Sugarman recognizes that liability does affect the behavior of problem-solving actors. He acknowledges, for example, that large commercial enterprises tend to make soplisticated cost-minimization and safety decisions, and also that their insurance rates frequently reflect their individual accident listories. ${ }^{261}$ In lis discussion of the Tarasoff decision, Sugarman cites evidence that most psycliotherapists liave become aware of the applicable doctrine and some liave clianged their practices in response to it. ${ }^{262}$ In addition, lie notes that the indirect costs of torts suits, including bad publicity, defense expenses, and diversion of managerial attention, can influence tlie risk-avoidance clioices of firms. ${ }^{263}$ In these and other instances, Sugarman replies that the tort system still does not attain a perfect level of deterrence, ${ }^{264}$ but this response misses the point. No system can aclieve perfect deterrence. The important issue is whether tort liability creates more effective deterrent incentives for problem-solving actors than would exist in the absence of liability. In one illustration, Sugarman describes an "imperfect" context in which insurance costs are internalized on a category of problemsolving actors ratlier than on the basis of individualized accident ratings. ${ }^{265}$ Internalization on specific actors may or may not be wortliwliile,

260. See Calabresi, supra note 3, at 669-70; Calabresi, supra note 111 , at 527-28.

261. See Sugarman, supra note 21 , at 574-75.

262. See id. at 566 n.34 (citing Tarasoff v. Regents of Univ. of Cal., $17 \mathrm{Cal} .3 \mathrm{~d} \mathrm{425,551} \mathrm{P.2d}$

334, 131 Cal. Rptr. 14 (1976)).

263. See id. at 563.

264. See id at 559-91.

265. See id. at 575. 
depending on transaction costs and the degree to which past experience is a reliable predictor of future accidents; but society may nonetheless benefit if liability encourages the entire class of actors to exercise greater care when the risks created by their activities are substantial. Contrary to Sugarman's all-or-nothing orientation, imperfect deterrence is often preferable to no deterrence. If tort law produces a "net social gain" in some accident contexts but not im others, ${ }^{266}$ the tort system should be retained in appropriate settings rather than simply abolished because it is imperfect.

It is important that the social engineering cure fit the malady. In "low-attention" risk categories, where typical actors are uninformed about risks and legal rules or do not engage in attentive problem-solving behavior, no refinement of liability doctrines is likely to promote social engineering tort goals to a siginficant degree. However, Sugarman describes problem-solving contexts $\mathrm{m}$ which deterrent incentives are diluted by ambiguity about which party would be hable, or by the low expected value of damage awards, or by the inability of many claimants to present their cases. ${ }^{267}$ In these settings, tort law may be reformed to make liability more certain and consistent in apphication, as I attempt to do in my liability system matrix. Similarly, numerous devices could reduce the transaction costs associated with tort litigation without substantially eroding the risk-avoidance incentives created by potential hability. ${ }^{268}$ Indeed, eliminating "low-attention" risk categories from the purview of the tort system would itself decrease the frequency and imstitutional costs of litigation. Because Sugannan lumps together many disparate criticisms of tort law, his analysis provides little insight on when the tort system should be retained, when it should be reforned, and when it should be replaced by alternative compensation strategies.

Another prominent theme in Sugarman's essay is that the tort system and "tailored" msurance plans fail to achieve "horizontal equity" because claimants often receive greater compensation than do victims of naturally occurring or accidentally self-inflicted injuries. ${ }^{269}$ One obvious distinction is that tortious accident losses are frequently more amenable to deterrence than are other types of injuries. To the extent that prob-

266. Sugarman questions whether tort law as a whole produces a "net social gain." See id. at 590. I do not, however, believe an analysis at that level of generality is desirable. If tort liability can sometimes induce efficient behavior modification by problem-solving actors, then the tort system should be retained in particnlar bilateral and unilateral problem-solving risk contexts, regardless of whether reliancc on alternative compensation systems is preferable in "low-attention" accident settings.

267. See id. at 564-73.

268. See, e.g., Rosenberg, The Causal Connection in Mass Exposure Cases: A "Public Law" Vision of the Tort System, 97 HARv. L. REV. 849, 887-924 (1984).

269. See Sugarman, supra note 21 , at $633-34$. 
lem-solving tortfeasors are not required to bear the full costs of their riskcreatimg activities, the incentives arising from potential liability will be diluted. Although questions of distributional "fairness" are outside the scope of this Article, it is not immediately apparent why tort victims should be precluded from obtaining full redress from responsible human agents just because society chooses not to provide complete coinpensation for other categories of victims.

Even if the principle of horizontal equity is accepted for the sake of argument, it does not follow that the solution is to eliminate tort law. The tort system could be reformed to achieve a much higher degree of consistency in compensation awards than at present. Following the example of worker compensations systems, legislatures could enact a prescribed schedule of allowable damages for various kinds of tortious injuries. Common law judges could restrict awards for pain and suffering, and could also develop stricter guidehines to limit other forms of dainages. Again, the remedy should fit the specific failing of the tort system. In my opimon, Sugarman does not demonstrate that considerations of "horizontal equity" justify the abohtion of tort law rather than tort reform in appropriate accident contexts.

\section{F. Boundary-Drawing Problems}

The demarcation between "high-attention" and "low-attention" risk categories will not always be clear in practice. There is a continuum of risks to which people devote more or less attention, and about which they possess more or less knowledge. Judges and legislators could not readily characterize all risks in the suggested manner, and yet they must make such determinations in order to select the appropriate liability rules or compensation systems in diverse accident contexts. Thus, the liability system matrix raises the prospect of boundary-drawing problems and occasional disagreements about how particular risks should be classified. For example, railroads should be considered problein-solving actors for most accidents arising from their transportation activities, ${ }^{270}$ but I do not believe the accident in the famous Palsgraf case $^{271}$ should be regarded as a "transportation-related risk" for which strict liability is appropriate. Rather, the defendant railroad in Palsgraf was in the same position as any property owner on whose premises an invitee is jostled or drops a package. A railroad cannot feasibly inspect all packages carried by passengers; it cannot otherwise control the contents of those packages; and it cannot foresee or guard against all the risks that those packages inay create. Moreover, this type of accident probably would not occur with

270. See supra text accompanying notes 162-71.

271. Palsgraf v. Long Island R.R. Co., 248 N.Y. 339, 162 N.E. 99 (1928). 
sufficient frequency for railroads to compile a meaningful actuarial history of losses related to package carrying. When a common carrier knows or can practicably determme that it is transporting explosives, it should be characterized as an informed problem-solving actor with respect to that risk. The opposite behavioral characteristic is appropriate in cases like Palsgraf where the risk cannot feasibly be discovered. ${ }^{272}$ The more precisely categories of "high-attention" risks must be defined, the more likely it is that disagreements will arise about how specific losses should be classified.

This Article has not been primarily concerned with the implementation problems presented by the recommended hability system matrix, but I believe that the critical distinctions under my approach are no more difficult, and often less difficult, for judges or legislators to make than are the determinations required by competing loss allocation systems. The traditional neghigence standard, for example, presupposes that courts can decide whether specified behavior is "reasonable" under all the circumstances. Precisely because this test is all-encompassing with respect to the range of factors that must be examined, many commentators have argued that courts are incapable of applying the negligence standard in a coherent and consistent manner. ${ }^{273}$ Numerous tort theorists have advocated strict liability approaches in attempts to simplify the basis on which liability should be assigned, yet these strategies also require legal resolution of difficult boundary-line issues. Professor Epstein, for instance, has argued that liability should be predicated solely on which actor "causes" the accident. ${ }^{274}$ Judge Posner rightly criticized this test on the grounds that causal analyses often lead to arbitrary distinctions and that Epstein's approach disregards the social utility of the actor's behavior. ${ }^{275}$ With equal accuracy, Posner observed that Calabresi's strict liability test fails to provide any framework for resolution of cases in which one party is the better decisionmaker while the other party is the better cost avoider. ${ }^{276}$ Calabresi also emphasized the need for categorical treatments of accident risks, without providing adequate guidance on how specific losses should be assigned to particular categories of activities

272. I do not mean to suggest here that the ability to foresee specific risks is always a prerequisite for characterization as an informed problem-solving actor. I intend to examine the relationship between foreseeability and problem-solving behavior in a future article on strict product liability.

273. See, e.g., G. CALABRESI, supra note 1, at 244-65; Calabresi, supra note 117, at 136; Rizzo, supra note 123, at 291-310. Even as strong an advocate of negligence as Judge Posner has conceded that courts do not in practice consider all material factors. See Posner, supra note 14, at 209 n.9.

274. See Epstein, supra note 129; Epstein, Defenses and Subsequent Pleas in a System of Strict Liability, 3 J. LEGAL STud. 165 (1974).

275. See Posner, supra note 14, at 217-20; Posner, Epstein's Tort Theory: A Critique, 8 J. LEGAL Stud. 457 (1979). But see Epstein, Causation and Corrective Justice: A Reply to Two Crities, $8 \mathrm{~J}$. LEGAL STUD. 477 (1979).

276. See Posner, supra note 14, at 213-15; see also supra notes 141, 179. 
or actors. It is, for example, unclear under his analysis which categories should bear the losses in Palsgraf, Vincent, and Kendall. ${ }^{277}$

Other commentators have recently argued that the adoption of competing liability doctrines should turn on whether people generally underestimate or overestimate particular kinds of risks, ${ }^{278}$ and on whether strict hability will drive up the prices of some products and will consequently encourage consumers to increase purchases of even riskier product substitutes. ${ }^{279}$ These proposals, like those of Calabresi and Epstein, would require relatively sophisticated determinations that are neither self-executing nor immune from inconsistencies in application. The fact that my recommendations would also present boundary-drawing problems in some cases is not a decisive criticism because all tort liability strategies necessitate difficult marginal characterizations. Again, the important question from an implementation perspective is, "Imperfect compared to what?" The proposed liability system matrix places primary emphasis on the decisionmaking attributes of categories of actors, and therefore reduces the need for legal deterininations of (1) the most efficient cost-minimizing choices in particular risk contexts, (2) the relative decisionmaking and cost-avoidance capabilities of different types of parties, and (3) the complex market interactions and behavioral predictions necessary for an assessment of price-avoidance deterrent effects. In return for the sacrifice of some degree of theoretical efficiency, my approach provides a more administrable and consistent legal test in the majority of accident contexts. Moreover, in contexts where at least one category of problem-solving actors can be identified, my approach

277. For Calabresi's discussion of Palsgraf, see Calabresi, suprà note 108, at 91-95. In my opinion, this discussion does not identify which party was the best cost-benefit decisionmaker and cheapest cost avoider. Instead, it supports my argument that neither party in Palsgraf was an effective problem solver with respect to the specific risk created. For references to Calabresi's discussion of Vincent, see supra notes 141-42. I did not find any discussion of Kendall in his writings, and I cannot see how Calabresi's strict liability test would differentiate between the dog-owner injurer and the dog-owner victim on a categorical level.

278. See Schwartz \& Wilde, supra note 5, at $1425-46,1457-59$. Their analysis stresses only one coguitive constraint, imperfect consumer information about risks, and ignores the effects on consumer decisionmaking of limited time, attention, and comprehensional capacity. A court under their scheme would not only have to guess whether buyers are likely to underestimate particular risks, but also the extent to which consumers will pay attention to particular risks while using products. These legal decisionmaking criteria are not self-evidently administrable.

279. See Henderson, supra note 217. The principal example he cited was that if strict liability is imposed on used car dealers, it may create a competitive price advantage for presunably riskier used cars sold by private owners in a noncommercial setting. See id. at 1081-1084. Henderson assumes that the two markets are independent, but that is doubtful. If the prices set by privatc used car sellers are derived from the "Blue Book" or in some other way are related to used car prices set by commercial dealers, then Henderson's example falls apart. When used car dealers raise their prices to cover the costs of strict liability, vehicle prices in the private noncominercial market would increase by a commensurate amount and no relative competitive disadvantage would be created. My point is that courts could seldom if ever make the kinds of economic judgments required under Henderson's treatment. 
assigns the principal responsibility for risk-avoidance and price-avoidance decisions to decentralized problem solvers rather than to courts, legislatures, or regulatory agencies, and thus provides a more realistic basis for reasonably efficient accident cost minimization.

\section{CONCLUSION}

Many "law and economics" analyses treat the relationship between loss allocation and beliavior modification reductively as if it were a proposition of logic: if liability is imposed, then efficient cost minimization must follow. In this Article, I argue for a more realistic treatment which recognizes that the social engineering effects of tort liability are dependent on the actual beliavior of people in diverse accident contexts, and that risk-avoidance behavior varies greatly in different contexts and among different categories of actors. Precisely because people respond differently to diverse risks, no single liability theory or alternative compensation system can achieve efficient results in all circumstances. I therefore recommend a situational analysis, with the paradigmatic term "problem-solving beliavior" used to reflect the conclusion that a particular class of actors typically understands and pays attention to a particular type of risk and the corresponding legal rules.

The central thesis of this Article is that tort liability is more likely to promote social engineering goals when accident costs are internalized on problem-solving actors rather than "low-attention" parties. Although uncertainty will occasionally arise about how specific risks slould be characterized, problem-solving behavior is most prevalent in institutional and coininercial settings that facilitate specialization in risk-avoidance decisionmaking and adaptation on the basis of feedback from recurring experiences. In accident contexts where these problem-solving attributes are uncommon, alternative coinpensation strategies should generally replace tort litigation because these systems would entail lower transaction costs with little real sacrifice of accident deterrence.

There are many interesting questions that I liave not addressed im this essay, including the respective roles of courts and legislatures in deciding whicll risks sliould be classified as "high-attention" and in matcling liability rules or compensation systeins with specific types of risks, ${ }^{280}$ the mechanisms through which parties can demonstrate the presence or absence of problem-solving behavior in particular cases, and

280. In "low-attention" risk contexts, where I believe that tort litigation serves little social engineering purpose, legislatures or administrative agencies would have to implement alternative compensation systems. Either legislatures or courts could impose the recommended liability strategies in unilateral and bilateral problem-solving accident contexts, but $I$ have not attempted liere to examine the merits of different institutional models for making the necessary characterizations and classifications. 
the proper scope of proximate causation doctrines in problem-solving accident contexts. I hope to explore these and related issues in subsequent articles, but my purpose here was to introduce the liability system matrix on a conceptual level and then to show that the paradigm of "problem-solving behavior" can be employed to criticize many current hability doctrines and to suggest more efficient approaches. My analysis is not fully developed at this point and will never produce perfectly efficient results in all cases; but I beheve it represents a significant incremental improvement over other commentators' attempts to provide a comprehensive social engineering theory of tort liability. 